\title{
STUDIES OF NEPHRITIS IN CHILDREN
}

\author{
I. NEPHROSIS *
}

\author{
HERMAN SCHWARZ, M.D., AND JEROME L. KOHN, M.D. \\ NEW YORK
}

During the past three years we have had the opportunity of studying about sixty cases of kidney disease in children. According to the clinical findings these cases seem to have fallen into four groups. By means of laboratory data we have endeavored to strengthen this classification so as to make it useful from a diagnostic and therapeutic standpoint :

Group I comprises cases which began either without apparent cause, in children seemingly in perfect health, or in which the mother had, perhaps, noticed that the child was pale. There was little or no elevation of temperature and apparently no accompanying disease. Edema of the face or legs first appeared. It spread rapidly to the remainder of the body. The edema was very persistent, or if it did disappear it showed a decided tendency to recur. There was no hematuria but the urine, at times, was diminished in quantity and always contained large quantities of albumin. The edema was the outstanding feature. The duration of the disease was months or years, and the patient showed no tendency to get well. This malady is known in the earlier literature as nephritis parenchymatosa and has more recently been termed nephrosis by Volhard. ${ }^{1}$ Others have used the terms nephropathia epithalialis, nephropathia tubularis and epithelial nephrosis.

Group II comprises cases which began acutely with or without an accompanying acute disease, often with temperature elevation and with or without edema, the edema usually being not extensive, often localized to the face, or to the face and the extremities, and never very persistent. Hematuria was a common symptom. The cases usually lasted a few weeks; occasionally they became subacute and the symptoms would continue a few months, or become chronic and extend for years. Cases of this type are known in the literature as acute nephritis, actite hemorrhagic nephritis or acute glomerulonephritis. When chronic, they are termed chronic glomerulonephritis.

Group III comprises cases observed in private practice for a period of months or years accompanied by an occasional acute stage, but with

* Received for publication, April 4, 1922.

* From the Pediatric Service and Pathologic Laboratory, Department of Physiologic Chemistry, Mount Sinai Hospital.

1. Volhard, F.: Die Doppelseitige Haematogischen Nierenkrankheiten, Berlin, 1918. 
none of the outward signs usually seen in kidney disease, such as edema, hematuria or high blood pressure. They are the cases termed by Heubner " "paedonephritis."

Group IV comprises cases characterized by marked pallor, headache, vomiting, polyuria, high blood pressure, retinitis, convulsions and death. The entire duration of the disease was about one year. Cases of this description are similar to the contracted kidney, or nephritis with hypertension of the adult.

\section{GROUP I : THE NEPHROSES}

The first group to be discussed is the nephroses. These are so named by Volhard ${ }^{1}$ and in most of our textbooks they are termed "nephritis parenchymatosa." We use this term strictly in a clinical sense, not having had the opportunity to verify or to classify these cases

TABLE 1.-Possible Remote Etiologic Factors

\begin{tabular}{|c|c|c|}
\hline Previous History & No. Cases & Years Ago \\
\hline Searlet fever. & 1 & 7 \\
\hline 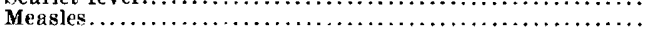 & 2 & 6 \\
\hline 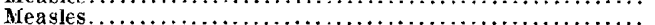 & $\overline{1}$ & 5 \\
\hline 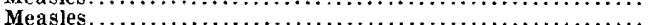 & 1 & 4 \\
\hline 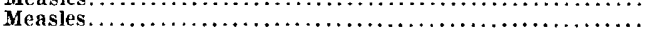 & $\mathbf{1}$ & $\begin{array}{l}4 \\
3\end{array}$ \\
\hline Measles. . & 1 & I \\
\hline 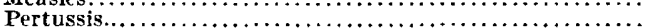 & 1 & 6 \\
\hline 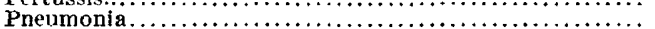 & $\begin{array}{l}\mathbf{l} \\
\mathbf{2}\end{array}$ & 5 \\
\hline Cervical adenitis........ & 1 & 3 \\
\hline 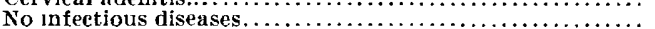 & 4 & \\
\hline
\end{tabular}

TABLE 2.-Recent Possible Etiologic Factor

\begin{tabular}{|c|c|c|c|}
\hline Case & Disease & No. Cases & When \\
\hline 5 & Tonsillitis.. & 1 & Six weeks before onset of disease \\
\hline 7 & Tubereulosis............ & 1 & Many months before and during disease \\
\hline 8 & Searlet fever..................... & 1 & Four months before ouset of disease \\
\hline 11 & Diphtheria,................ & I & Four months before onset of disease \\
\hline 14 & 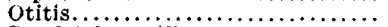 & 1 & Concomitant with onset of disease \\
\hline 16 & Scarlet fever (?)................... & 1 & Four weeks before onset of disease \\
\hline
\end{tabular}

from a pathologic standpoint. There are seventeen cases in which histories and general course conform more or less to the description given above.

Etrolcgy.--In discussing this type of kidney disease and, in fact, in all disease, it is important to examine closely the life history of the patient; for example, a systolic murmur at the apex demands more consideration if one knows there has been a previous chorea.

In Table 1 it will be seen that as a remote etiologic factor only one patient had scarlet fever; five patients had measles, one pertussis, one pneumonia, one adenitis and four had no infectious diseases whatever.

2. Heubner, O.: Kinderkrank., Ed. 3 2: p. 502. 
Although most of these cases did not exhibit an acute condition at the onset of the symptoms, in Table 2 we have tabulated some of the recent acute diseases of these patients. In eleven cases there had been no recent disease so far as we could ascertain, but in five cases some recent disease had preceded this onset.

In analyzing the history of some of these cases, it is interesting to note that one patient (Case 5) had scarlet fever seven years ago. Whether the kidney was damaged at that time and whether the recent tonsillitis was an exciting factor, cannot be determined, for unfortunately we have no accurate interviewing history. Another patient (Case 14) had a recent otitis, otherwise was apparently well but had always had a sallow complexion. A third patient (Case 8) had a questionable scarlet fever four months previously, but was apparently well until swelling of the face was first noted. As is well known, the toxin of scarlet fever usually affects the vascular and not the tubular portion of the kidney which is said to be the lesion in nephrosis. Yet at times, as Heubner ${ }^{3}$ has shown pathologically, a tubular nephritis may develop during the course of a scarlet fever infection. Case 16 is a similar one which seemed to develop soon after an attack of a possible scarlet fever, for a sister in the family had scarlet fever at that time. It may, therefore, be possible that the virus of scarlet fever may, at times, give this clinical picture.

As is proven by Volhard's ${ }^{1}$ statistics, tuberculosis may be the etiologic factor, for of fifty-five cases of nephrosis cited, fifteen had tuberculosis. Only one of our cases had a possible tubercular etiology. The Pirquet reactions in the remaining cases were negative.

Case 2 is of interest, the patient having had diphtheria a short time previously. In diphtheria, in contrast to scarlet fever, there may be a distinct tubular involvement of the kidney. The diphtheria toxin given intravenously to animals regularly produces an involvement of the kidney tubules, and at the height of the disease albumin and casts appear. Feldman ${ }^{4}$ found an involvement of the kidney in 12 per cent. of his cases of diphtheria. Dorner ${ }^{5}$ found this type of kidney disease in 6.7 per cent. of his cases. Edema, however, was rarely present, and hematuria and a rise in blood pressure were absent. An interesting clinical fact worth noting is that of Feldman's seventy-three cases of diphtheria complicated by a nephrosis, forty-three patients died, showing the added gravity of this condition in diphtheria. Very few of the cases which recover from diphtheria, however, result in this form of kidney disease.

3. Heubner, O.: Jahrb. f. Kinderh. 77:1, 1913.

4. Feldman, H.: Monatschr. f. Kinderh. 19:491, 1921.

5. Dorner, G.: Quoted by Feldman, Klin. Stud. z. Path. in Behand. der Diphth. Jena, 1918. 
Syphilis may cause a symptom complex similar to the one we have studied. Munk ${ }^{6}$ describes the clinical picture as one with marked anemia, edema, oliguria, albuminuria, casts and low blood pressure. In our cases the Wassermann reaction was uniformly negative.

Exposure.-Inasmuch as exposure to cold has often been described as an etiologic and exciting cause of kidney disease, it was interesting to see at what time of the year the symptoms in our cases were first noted. It was found that eight cases began in the cold months and nine in the warm months. Although so few cases have been studied, cold or exposure cannot be an important causative factor.

Sex.-Sex seems not to be a predisposing cause. Eight of the patients were females and nine were males.

Age.-Ten of the seventeen patients were of the preschool age giving, perhaps, added evidence of the unimportance of the infectious diseases (Table 3 ).

There remains, therefore, a considerable number of these cases without any known etiologic factor: the genuine "nephrosis" cases of

TABle 3.-Age of Patients

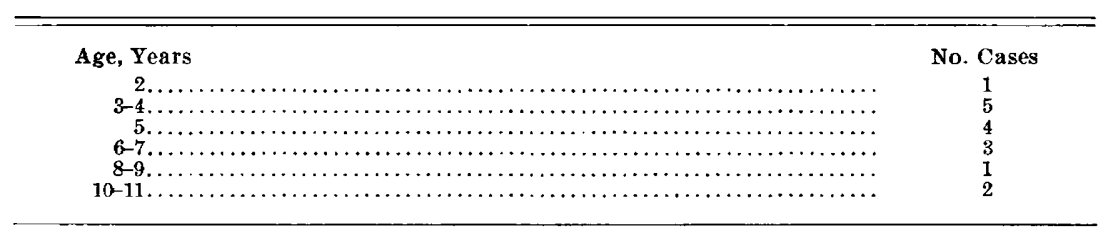

Volhard. He, as well as Epstein, ${ }^{7}$ repeatedly pointed to a general metabolic disturbance, perhaps of the ductless glands, as a cause of this disease, and that these cases do not seem to be primarily a disease of the kidney.

Symptoms: Onset.- In some of our cases there was a history of pallor or a generally subnormal condition existing for some months previously. In a few cases there was a distinct history of malaise, vomiting and headache; in the majority of cases, however, the first symptom noticed by the parents, was the swelling about the face, the edema increasing with great rapidity. In ten cases the edema began in the face and within twenty-four hours the legs were involved. In other cases the edema of the legs and face occurred simultaneously, and in the course of about a week the other subcutaneous tissues were also involved.

Temperature.-Temperature elevation was not usuaily present, and the children were not acutely ill; the throat was generally in fairly

6. Funk, F.: Ztschr. f. klin. Med. 78:1. 1913.

7. Epstein, A. A.: Am. J. M. Sc. 163:167, 1922. 
good condition, only three of the seventeen patients had enlarged tonsils. These children as contrasted with our cases of acute glomerulonephritis were not of the exudative or lymphatic type.

Heart.-The heart is usually involved whenever there is general anarsaca, and ordinary physical examination often does not show the true picture. Alwens and Moog, ${ }^{8}$ by means of careful roentgen-ray measurements and the rapidly changing heart borders, showed that there is a dilatation of the heart in acute nephritis. Wessler, ${ }^{3}$ in like manner, showed that there was distinct hypertrophy in cases of chronic nephritis. So, in our cases, by means of the roentgen ray, it was possible to follow the change in the heart outline according to the presence or absence of general edema. From the pictures it can definitely be stated that there is usually a hydropericardium whenever there is marked general edema.

Chest.-In the pleural cavities, fluid is often present, as demonstrated by the roentgen ray when no signs by ordinary physical examination can be elicited. It is impossible to explain just why the left side of the chest seems more often affected. These cases are often complicated by the infection of the bronchi and the lungs.

Abdomen.-The abdominal cavity, like the pericardium and the pleura, is usually involved but to a much greater extent. Ascites was present at one time or another in all our cases and required paracentesis. The character and analysis of these fluids will be detailed in another portion of the paper.

Edema.-Edema of the subcutaneous tissues was present to a greater or lesser degree at all times. Even when there is no demonstrable edema, there is a marked disposition to it. During marked edema the skin and subcutaneous tissues are greatly distended, and there is a tendency to skin infection, which, however, from our experience, seems not as marked as in the adult, for only once did we see an erysipelas.

Edema of the face and brain: Edema of the face is usually present at one time or another. We believe that edema of the brain may also be present and cause cerebral symptoms erroneously termed uremia. Case 15 had such a symptom complex. The child complained of headache, became semiconscious, cyanotic and would cry out, the attack lasting about twenty minutes and recurring a few times in twenty-four hours. A week later the child was in a semicomatose condition for eighteen hours. During these attacks there was no nitrogen retention of the blood, no increased blood pressure and the eyegrounds were normal.

Abdominal Pain.-This is present at times with a great degree of severity and may be located about the umbilicus. This may be due to an edema of the intestinal wall, but a pneumococcus peritonitis must always suggest itself.

8. Alwens and Moog: Deutsch. Arch. f. klin. Med. 133:364, 1920.

9. Wessler, H.: Arch. Int. Med. 14:517 (Nov.) 1914. 
Diarrhea.-May occur and is often very severe, this probably being a means of getting rid of the edema fluid. In one of our cases there was a marked diarrhea with mucus and blood, lasting for over two weeks, during which time the ascites and subcutaneous edema disappeared, the child losing 14 pounds in weight.

Anemia.-The anemia in this disease is usually of a mild secondary type, and it is only toward the end of the disease that the hemoglobin may drop below 50 per cent., the red blood cells (Table 4) rarely falling

TABLE 4.-BLood Count

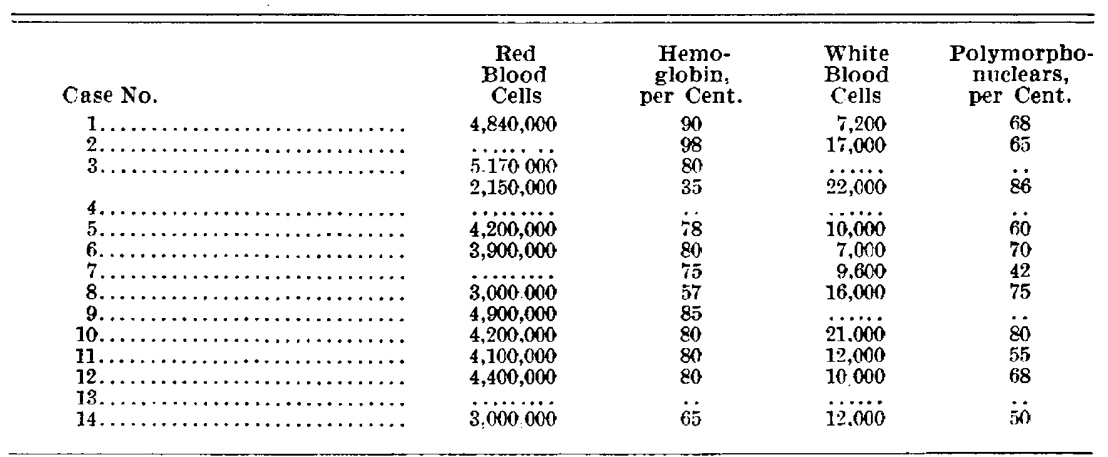

TABLE 5.-Blood Pressure

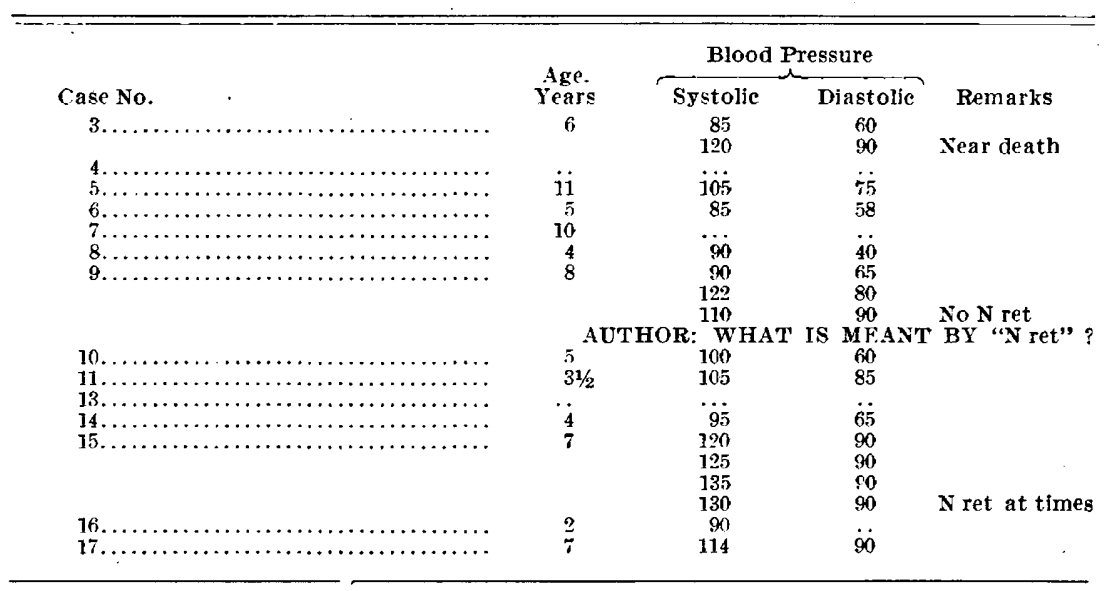

below 3,000,000, there being not much difference in the count before, during or after the disappearance of the anasarca. These children often look very anemic but the absolute degree of anemia is never very great.

Blood Pressure.-The blood pressure (Table 5) is practically normal. In five cases the systolic pressure rose above 115 and reached 135 in one case. The question of blood pressure in children is always a mooted one, a neurotic temperament, crying and other circumstances may make the blood pressure vary. When the children are doing badly 
or are near death, as in Case 3 , the blood pressure is apt to rise. In Case 15 there was persistently high blood pressure, but only on one occasion was there a high nonprotein nitrogen, later in the disease the nitrogen decreased, yet the systolic blood pressure remained from 125 to 135 . Dorner ${ }^{10}$ showed that the ingestion of fluid does not cause the blood pressure to rise in cases of nephrosis, for presumably the blood vessels permit water to penetrate into the tissues and no plethora is established. This was confirmed by showing that the total solids of the blood were unchanged. Even intravenous administration of fluid does not cause an increase of the blood pressure. He shows that in addition to increased blood volume there must be a certain contractibility of the blood vessel walls before there can be an increase in blood pressure. In the so-called water test, which will be discussed in detail later, it was observed that the ingestion of large quantities of fluid in a comparatively short time did not increase the blood pressure.

The phenolsulphonephthalein test in these cases showed relatively poor excretion. The test, however, was very unsatisfactory. The dye injected into the edematous tissues is absorbed irregularly and reaches the kidney much more slowly than the two hours alloted to the test, and when given intravenously, the test may also not be accurate because of the permeability of the vessel walls. In one case in which it was given subcutaneously, 25 per cent. of the dye was excreted in two hours with a urine output of 70 c.c.; given intravenously, 32 per cent. was excreted in 100 c.c. of urine. Hessel ${ }^{11}$ showed that intravenous injection was, perhaps, a little more satisfactory.

Blood.-The physical character of the blood exhibits a striking quality quite different from the normal, for on drawing blood from the vein and permitting it to coagulate, the serum separates quickly and is distinctly milky, instead of being the normal straw colored, clear serum.

The chemical examination of the blood in the light of the many new microchemical methods which have been devised in the last few years is extremely interesting, examinations being made of the urea, nonprotein nitrogen, uric acid, creatinin, cholesterol, carbon dioxid, sugar, total serum fat and total serum protein and serum chlorids. ${ }^{12}$

10. Dorner, G.: Deutsch. Arch. f. klin. Med. 133:21, 1920.

11. Hessel, K.: Deutsch. Arch. f. klin. Med. 114:396, 1914.

12. Methods: Urea-urease (Marshal1); nomprotein nitrogen-digestion and titration; uric acid and creatinin with Kuttner's modification of Folin's method; sugar-with Epstein's modification of Benedict's method; cholesterol-Bloor's method; carbon dioxid-Van Slyke's gasometric method; serum chlorids-Van Slyke and Donleary and some by the method of A. S. Wetmore (J. Biol. Chem. 45:113 [Dec.] 1920); total serum fat-extraction with ether and petrolic ether, using the Roese-Gottlieb method (Rohrig tube); total serum protein-total nitrogen minus nonprotein nitrogen $\times 6.25$. 
From Table 6 it will be seen that the urea nitrogen, the nonprotein nitrogen, uric acid and creatinin nitrogen showed very little or no change from the normal, the addition of protein to the food not seeming to affect these values. In changing from a carbohydrate or a karrel diet to a high protein diet very little increase in these values occur. This blood composition, as we will show in a later portion of the article, is one in marked contrast to that seen in cases of acute and chronic nephritis. The nephroses rarely show any retention of nitrogenous substances in the blood, and thus apparently do not terminate in fatal uremia. The coma and convulsions sometimes seen may be due to an acidosis (Case 8) or to an edema of the brain (Case 15).

Case 3 was an exception. In 1915, the child was in Bellevue Hospital, suffering from edema. He was admitted to Mt. Sinai Hospital

TABLE 6.-Nitrogenous Elements in the Blood

\begin{tabular}{|c|c|c|c|c|c|c|c|c|c|}
\hline Case & Urea $\mathbf{N}$ & N P N & $\underset{\text { Acid }}{\text { Urie }}$ & $\begin{array}{l}\text { Creat- } \\
\text { inin N }\end{array}$ & Case & Urea $\mathbf{N}$ & $\mathbf{N} \mathbf{P} \mathbf{N}$ & $\begin{array}{c}\text { Uric } \\
\text { Acid N }\end{array}$ & $\begin{array}{l}\text { Creat- } \\
\text { inin N }\end{array}$ \\
\hline 1 & $\begin{array}{l}21.4 \\
14.0\end{array}$ & $\begin{array}{l}54.6 \\
60.0\end{array}$ & $\begin{array}{l}1.5 \\
1.4\end{array}$ & $\begin{array}{l}1.5 \\
1.1\end{array}$ & 10 & $\begin{array}{l}15.4 \\
14.1\end{array}$ & $\begin{array}{l}46.7 \\
45.5\end{array}$ & $\begin{array}{l}1.7 \\
4.2\end{array}$ & $\begin{array}{l}1.2 \\
1.3\end{array}$ \\
\hline 2 & $\begin{array}{l}12.6 \\
12.6\end{array}$ & $\begin{array}{l}39.5 \\
56.0\end{array}$ & 1.9 & 1.5 & 11 & $\begin{array}{l}16.0 \\
19.6 \\
16.8\end{array}$ & $\begin{array}{l}46.9 \\
53.4 \\
32.2\end{array}$ & $\begin{array}{l}2.0 \\
1.6 \\
2.0\end{array}$ & $\begin{array}{l}1.2 \\
1.7 \\
1.3\end{array}$ \\
\hline $\begin{array}{l}3 \\
4\end{array}$ & $\begin{array}{r}114.0 \\
19.6\end{array}$ & 206.0 & 6.0 & 9.2 & 12 & $\begin{array}{l}18.2 \\
18.2\end{array}$ & $\begin{array}{l}45.5 \\
32.2\end{array}$ & $\begin{array}{l}1.9 \\
1.5\end{array}$ & $\begin{array}{l}1.2 \\
1.0\end{array}$ \\
\hline & $\begin{array}{l}19.0 \\
14.0\end{array}$ & & & & 13 & 12.6 & 32.9 & $\ldots$ & 1.2 \\
\hline 5 & $\begin{array}{l}11.2 \\
11.2\end{array}$ & $\begin{array}{l}37.5 \\
35.0\end{array}$ & $\begin{array}{l}2.5 \\
3.4\end{array}$ & $\begin{array}{l}1.3 \\
1.8\end{array}$ & 14 & $\begin{array}{l}12.2 \\
25.2 \\
21.0\end{array}$ & $\begin{array}{l}42.0 \\
50.0 \\
49.0\end{array}$ & $\begin{array}{l}1.6 \\
5.0 \\
2.8\end{array}$ & $\begin{array}{l}1.2 \\
1.5 \\
1.5\end{array}$ \\
\hline 6 & $\begin{array}{l}22.4 \\
14.0\end{array}$ & $\begin{array}{l}45.0 \\
35.5\end{array}$ & $\begin{array}{l}3.0 \\
1.8\end{array}$ & $\begin{array}{l}1.3 \\
1.2\end{array}$ & & 19.6 & 28.6 & 1.0 & 1.0 \\
\hline 7 & 21.0 & & & 1.3 & 15 & $\begin{array}{l}23.8 \\
12.6\end{array}$ & $\begin{array}{l}82.0 \\
49.5\end{array}$ & 3.0 & 1.0 \\
\hline & 22.4 & $\dddot{54.5}$ & i.s & 1.7 & & 19.6 & 41.5 & 1.5 & 1.4 \\
\hline 8 & 13.4 & $\begin{array}{l}87.5 \\
41.7\end{array}$ & $\begin{array}{l}4.0 \\
\because .\end{array}$ & 2.6 & $\cdot$ & $\begin{array}{l}4.4 \\
30.0 \\
35.2\end{array}$ & $\begin{array}{l}1.0 \\
56.4 \\
51.0\end{array}$ & $\begin{array}{l}.1 \\
1.8 \\
1.5\end{array}$ & $\begin{array}{l}1.0 \\
1.3 \\
1.2\end{array}$ \\
\hline & 32.0 & 63.0 & 4.4 & 3.1 & & 12.6 & 37.0 & 2.4 & 1.1 \\
\hline & 12.6 & 40.0 & 4.5 & 1.5 & 16 & 18.2 & & 1.5. & \\
\hline 9 & $\begin{array}{l}18.2 \\
15.4 \\
18.2\end{array}$ & $\begin{array}{l}35.9 \\
44.4 \\
45.6\end{array}$ & $\begin{array}{l}1.3 \\
3.2 \\
2.8\end{array}$ & $\begin{array}{l}1.1 \\
2.1 \\
1.0\end{array}$ & & $\begin{array}{l}32.2 \\
47.6 \\
37.8\end{array}$ & $\begin{array}{l}66.5 \\
87.6 \\
75.0\end{array}$ & $\begin{array}{l}2,0 \\
\ldots \\
\ldots\end{array}$ & $\begin{array}{l}1.6 \\
\ldots \\
\ldots\end{array}$ \\
\hline & $\begin{array}{l}21.6 \\
21.6\end{array}$ & 46.7 & 2.6 & 1.5 & 17 & 11.2 & $\ldots$ & $\ldots$ & $\ldots$ \\
\hline
\end{tabular}

in 1917 with a history of recurring edema. He was readmitted to Mt. Sinai Hospital in 1919. On this last admission the child was in a moribund and comatose condition. The blood analysis was as follows: urea nitrogen, 114; nonprotein nitrogen, 206; uric acid nitrogen, 6; creatinin, 9; cholesterol, 0.424 per cent., showing an abnormally high nitrogen retention and in addition a great increase in the cholesterol. The fundi were negative. Unfortunately, there were no previous chemical examinations of the blood. But with this marked increase in cholesterol and the history as noted, it is likely that we had a case of nephrosis, the patient dying with the symptoms of uremia.

Serum Protein.-The total serum protein of the blood in this condition as shown by Epstein, ${ }^{13}$ Volhard $^{1}$ and others is almost always

13. Epstein, A. A.: Am. J. M. Sc. 154:638, 1917 . 
reduced, often markedly so. Normally, the serum protein content of the blood after the second year of life is between 7 and 8 per cent. (Utheim ${ }^{14}$ ); in our control cases the protein content in most cases was about 7.3 per cent. It is lowest in the prematurely born and gradually increases up to the second year; it is also low in infants with chronic intestinal disturbance of the so-called athreptic type, ${ }^{15}$ and in surgical shock. ${ }^{16}$ It is high in conditions in which there is a sudden or continuous fluid loss, such as persistent diarrhea and vomiting, without a sufficient fluid intake, as in intestinal intoxication of infants and in asiatic cholera. In analyzing our cases it will be seen from Table 7 that in only one case did the protein content approach the normal. In all other cases it was low, and in seven it was below 5 per cent.

TABLE 7.-Total Serum Protein

\begin{tabular}{|c|c|c|c|c|c|}
\hline Case & Date & Urea $\mathbf{N}$ & $\begin{array}{l}\text { Total } \\
\text { Protein, } \\
\text { per Cent. }\end{array}$ & $\begin{array}{l}\text { Sodium } \\
\text { Chlorid, } \\
\text { Mg. }\end{array}$ & Remarks \\
\hline 1 & $12 / 11 / 21$ & 12.6 & 6.2 & $\cdots$ & After 2 years illness; no edema \\
\hline 4 & $\begin{array}{l}11 / 20 / 21 \\
12 / 12 / 21\end{array}$ & $\begin{array}{l}19.6 \\
14.2\end{array}$ & $\begin{array}{l}4.2 \\
4.35\end{array}$ & $\cdots$ & $\begin{array}{l}\text { Duration } 6 \text { months; edema } \\
\text { No edema }\end{array}$ \\
\hline 5 & $/ 21$ & 11.2 & 5.5 & $\ldots$ & Duration 4 months; edema \\
\hline 6 & $\begin{array}{r}7 / 22 / 21 \\
12 / 7 / 21\end{array}$ & $\begin{array}{l}14.0 \\
11.2\end{array}$ & $\begin{array}{l}4.96 \\
5.4\end{array}$ & $\begin{array}{l}6.3 \\
\cdots\end{array}$ & $\begin{array}{l}\text { Duration } 3 \text { weeks; little edema } \\
\text { No edema }\end{array}$ \\
\hline 8 & $\begin{array}{r}4 / 4 / 21 \\
4 / 30 / 21 \\
11 / 19 / 21\end{array}$ & $\begin{array}{l}14.4 \\
32.5 \\
40.0\end{array}$ & $\begin{array}{l}5.6 \\
5.3 \\
4.3\end{array}$ & $\begin{array}{l}5.6 \\
\ldots \\
\cdots\end{array}$ & $\begin{array}{l}7 \text { months illness; edema } \\
\text { Fdema } \\
\text { Very slight edema }\end{array}$ \\
\hline 9 & $\begin{array}{l}3 / 9 / 21 \\
4 / 27 / 21\end{array}$ & $\begin{array}{l}18.2 \\
18.0\end{array}$ & $\begin{array}{l}5.6 \\
4.46\end{array}$ & $\dddot{5} .6$ & $\begin{array}{l}\text { Duration } 9 \text { mos.; not muci edema } \\
\text { Fdema }\end{array}$ \\
\hline 10 & $4 / 13 / 21$ & 15.4 & 4,81 & 6.0 & Duration 1 year; edema \\
\hline 11 & $\begin{array}{r}4 / 25 / 21 \\
11 / 25 / 21\end{array}$ & $\begin{array}{l}16.8 \\
14.0\end{array}$ & 6.3 & $\begin{array}{l}4.9 \\
\cdots\end{array}$ & $\begin{array}{l}\text { Duration } 7 \text { months; no edema } \\
\text { Slight edema }\end{array}$ \\
\hline 12 & 4/ $1 / 21$ & 18.2 & 5.9 & 6.0 & History 5 months; edema \\
\hline 14 & $10 / 10 / 21$ & 19.6 & 4.13 & $\ldots$ & $\begin{array}{l}\text { Duration } 10 \text { months; moderute } \\
\text { edema }\end{array}$ \\
\hline 15 & $7 / 21 / 21$ & 30.8 & 5.0 & 6.7 & $\begin{array}{c}\text { Duration } \\
\text { edema }\end{array}$ \\
\hline 16 & $\begin{array}{l}4 / 9 / 21 \\
8 / 24 / 21\end{array}$ & $\begin{array}{l}18.2 \\
47.6\end{array}$ & $\begin{array}{l}5.7 \\
7.15\end{array}$ & $\begin{array}{l}5.5 \\
\cdots\end{array}$ & $\begin{array}{l}\text { Duration } 1 \text { month; edema } \\
\text { Edema }\end{array}$ \\
\hline 17 & $12 / 28 / 21$ & 11.2 & 4.2 & $\cdots$ & Edema \\
\hline
\end{tabular}

We cannot, however, definitely assert that the diminished serum protein is proportionate to the intensity or the duration of the disease. One of our severest cases (Case 16; the child finally succumbing) had a serum protein content of 7.15 per cent.; on the other hand, one case (Case 11) had a serum protein content of 6.3 per cent. while in the hospital, and seven months later, although the child was in fairly good condition the protein decreased to 4.2 per cent.

Epstein ${ }^{2}$ and others have shown that normal'y the serum albumin fraction of the total serum protein is 65 per cent., and the globulin

14. Utheim, K.: Am. J. Dis. Child. 20:366 (Nov.) 1920

15. Marriott, W. McK.: Am. J. Dis. Child. 20:461 (Dec.) 1920.

16. Smith, H. P.; Belt, A., and Whipple, G. W.: Am. J. Physiol. 52:72, 1920. 
fraction almost 35 per cent. of the total, but that in this type of kidney condition just the reverse is true, the globulin predominates. Unfortunately, we were unable to make these determinations.

The significance of this lowered protein content is difficult to explain, except that it may be one of the factors in the production of the edema. Epstein does not think it is due to the hydremia or migration of serum through the capillary walls. It is true that in some of our cases the plasma volume was altered, the corpuscles in relation to the plasma being reduced in quantity. However, this was not always the case. Nonenbruch, ${ }^{17}$ in some experimental work, shows that the change of serum protein does not follow the erythrocyte values. At the end of a saline or gelatin infusion, the protein was lower than could be accounted for by the decrease of the red blood cells. In none of our cases did we find the red cell ration above normal.

Epstein also believes one must take into consideration the tremendous albumin loss in the urine, for these patients pass large amounts of albumin, sometimes for years, even after they are clinically well. We have never seen a case in which the urine was free from albumin, even after three years.

The work of Loeb ${ }^{18}$ on the colloidal properties of protein, and that of Palmer, Atchley and R. F. Loeb ${ }^{19}$ on the conductivity of salts in the blood when there is a low serum protein may have important bearing on this condition. One must remember, however, that "in vivo" the hydrogen ion concentration and the sodium chlorid content of the blood is constant, the serum protein being the variant in this type of nephritis. These authors suggest a mechanical interference by the protein. Whipple ${ }^{16}$ suggests that the protein may exercise a strong stabilizing and protective influence in maintaining a relationship of the circulating blood to the body cells.

Cholesterol and Fat in the Blood.-One of the most striking changes in the chemical composition of the blood in nephrosis is a marked increase in the cholesterol and the fat. This was first pointed out by Chauffard ${ }^{20}$ and used by Stepp ${ }^{21}$ and Post ${ }^{22}$ as an aid in the diagnosis of this form of kidney disease.

Before discussing this phase of the disease, it might be interesting to summarize some of our knowledge concerning cholesterol in the body, and especially in its relation to infants and children. From many examinations of normal children by the methods used in our laboratory

17. Nonenbruch, W.: Arch. f. Exper. Path. u. Pharmakol. 91:218, 1921.

18. Loeb, J.: J. Gen. Physiol. 1:237, 363, 483, 559, 1920.

19. Palmer, W. W.; Atchley, D. W., and Loeb, R. F.: J. Gen. Physiol. 3: $801,1921$.

20. Chauffard, A., and Grigaut, A.: Ann. de méd. 8:149, 1920.

21. Stepp, W.: Deutsch. Arch. f. klin. Med. 127:439, 1918.

22. Post, F.: Deutsch. Arch. f. klin. Med. 128:61, 1918. 
and also according to Beumer, ${ }^{23}$ Stern, ${ }^{24}$ Bloor ${ }^{25}$ and others, the cholesterol content of the blood of young infants and children was found to be approximately the same as that of adults, viz. 0.120 per cent. to 0.220 per cent. The cholesterol in breast milk ${ }^{26}$ is very low during the first day of lactation ( 0.00035 per cent.), then increases rapidly, so that at the end of the first week it is 0.052 per cent., and at the end of the fifth week it again has decreased. This increase in the cholesterol may be of great importance in the new-born period of the child's life. The cholesterol is not found as such in milk but is in the form of an ester. ${ }^{27}$ Woman's milk contains 0.139 per cent. and cow's milk 1.26 per cent.; probably a little less than that found in the blood.

The cholesterol content of the various organis of the body has been investigated by Beumer ${ }^{28}$ and Chauffard. ${ }^{20}$ The suprarenal is the principal depot for cholesterol, containing about $56 \mathrm{gm}$. of cho'esterol per thousand gm. of suprarenal tissue. The liver and kidney contain $2.9 \mathrm{gm}$. per thousand $\mathrm{gm}$. of the respective tissues, the other organs and tissues containing but a very small amount.

The cholesterol content of the blood is low in all forms of anemia, in moribund conditions, in scarlet fever and in Addison's disease. In rickets, the exudative diathesis, and in cases of edema due to "Mehlnährschaden" 29 it is normal. It is increased in syphilitic aortitis and in some cases of hypertension. Splenectomy ${ }^{30}$ causes a distinct rise in the cholesterol content of the blood, and finally the cholesterol content of the blood is markedly increased in the form of nephritis which we are studying.

The metabolism of cholesterol is as yet very little understood. There is according to Blackfan and Gamble ${ }^{31}$ a large negative balance in infants, and they believe that cholesterol may be synthetized in the body. The relation of cholesterol to the maintenance of growth does not depend, apparently, on the amount of cholesterol in the food. Wacker and Beck $^{32}$ showed that the cholesterol metabolism was dependent on the fat metabolism, and they believe that the cholesterol is carried out with the fat in the stools, thus explaining the negative balance. They showed that the fat partitions in the stools could be altered by giving cholesterol. Chauffard ${ }^{20}$ and his co-workers have done a great deal of work in

23. Beumer, H.: Deutsch. Arch. f. klin. Med. 68:105, 1920.

24. Stern, G.: Ztschr. f. Kinderh. 25:129, 1920.

25. Bloor, W. R.: J. Biol. Chem. 49:201, 1921.

26. Wacker, L., and Beck, K. F.: Ztschr. f. Kinderh. 27:288, 1921.

27. Beuner, H.: Monatsch. f. Kinderh. 15:581, 1919.

28. Beumer, H.: Monatschr. f. Kinderh. 18:443, 1920.

29. Beumer, H.: Monatschr. f. Kinderh. 15: 588, 1920.

30. Medick, E.: Biochem. Ztschr. 59:419, 1914.

31. Blackfan, K. D., and Gamble, J. S.: J. A. M. A. 73:218 (July 19) 1919.

32. Wacker, L., and Beck, K. F.: Ztschr. f. Kinderh. 29:331, 1921. 
trying to clear up this problem. They attempted to show that the cholesterol metabolism depends on (1) food intake; (2) glands of internal secretion; (3) the liver.

1. When cholesterol is taken with the food, the cholesterol in the serum increases slightly but returns to a normal level soon after.

2. Of the glands of internal secretion the suprarenal alone is to be considered and seems to be the main depot of the cholesterol, but whether cholesterol is secreted there or only stored in the suprarenal is not known. In unilateral suprarenalectomy, Troissier and Grigant ${ }^{33}$ showed that the cholesterol in the blood was high for a few days. Stimulation of the splanchnic plexus to the suprarenal vessels increases the cholesterol output.

3. As for the liver and bile, it has been shown that the cholesterol is excreted in the bile, and, in fact, some think it is the precursor of the bile salts, ${ }^{34}$ yet the amount excreted does not approach the total cholesterol destroyed and, perhaps, the liver destroys the remainder (Chauffard).

The intimate association of fat and cholesterol has been pointed out especially by Verse ${ }^{35}$ and Bloor. ${ }^{25}$ Verse by giving fat alone to rabbits did not produce a lipemia and the animal did poorly, and when he gave cholesterol without fat there was again no lipemia, but the blood cholesterol increased. When he gave cholesterol and fat he produced a lipemia and the animal gained weight. If either one was stopped, the lipemia disappeared. If fat were fed to animals for a time it would take but a little cholesterol to cause a lipemia; but if cholesterol were given alone for a time, it would take a considerable period for the lipemia to develop on giving fat. The blood figures showed better absorption of cholesterol in the presence of fat. The serous cavities in some animals contained fluid, but this fluid had only a very faint trace of cholesterol, but a considerable amount of fat, showing that the fat was more permeable to the capillaries than the cholesterol.

Bloor ${ }^{25}$ showed that the normal fat content of the blood is between 0.5 to 0.8 per cent. Milkiness in serum is due to a high fat content, but at times one can get a high fat content without milkiness, as we have seen in some of our cases. After the ingestion of food, he showed there was first an increase of fat in the blood, then of lecithin and finally of cholesterol. The normal lecithin-cholesterol ratio was about 0.96 per cent. Conversely, as the cholesterol was the last to increase in the normal subject so it was also the last to reach its normal level.

The features of a persistent lipemia are: (1) Increase of lecithin and and cholesterol with increase of fat; (2) the greatest increase over

33. Troissier, J., and Grigaut, A.: Presse méd. 20:1081, 1912.

34. Wacker, L., and Beck. K. F.: Berl. klin. Wchnschr. 58:453, 1921.

35. Verse, M.: Beitr. z. Path. Anat. u. z. allg. Path. 63:789, 1917. 
the normal is the fat content; next the cholesterol and finally the lecithin. The origin of the fat in a persistent lipemia is (a) food; (b) the fat deposits in the body.

The origin of the lecithin is from a synthesis of the fat and phosphorus of the body. The origin of the cholesterol is unknown,

TABLE 8.-Cholesterin and Fat in Brood

\begin{tabular}{|c|c|c|c|c|}
\hline Case & Date & $\begin{array}{l}\text { Cholesterin, } \\
\text { per Cent. }\end{array}$ & Fat & Remarks \\
\hline 1 & $10 / 10 / 21$ & 0.200 & $\cdots$ & $\begin{array}{l}\text { Two years after first admission, no edema at } \\
\text { present }\end{array}$ \\
\hline 3 & $7 / 15 / 19$ & 0.424 & 1.27 & $\begin{array}{l}\text { Died soon after admission; very edematous on } \\
\text { admission }\end{array}$ \\
\hline 4 & $\begin{array}{r}11 / 21 / 21 \\
12 / 12 / 21 \\
1 / 13 / 22\end{array}$ & $\begin{array}{l}0.628 \\
0.360 \\
0.242\end{array}$ & $\begin{array}{l}\cdots \\
\cdots\end{array}$ & $\begin{array}{l}\text { Markedly edematous } \\
\text { Edema gone } \\
\text { Edema gone }\end{array}$ \\
\hline 5 & $\begin{array}{r}0 / 1 / 21 \\
9 / 17 / 21 \\
9 / 24 / 21 \\
11 / 18 / 21\end{array}$ & $\begin{array}{l}0.474 \\
0.450 \\
0.552 \\
0.592\end{array}$ & $\begin{array}{l}\dddot{1.2} \\
\ldots \\
\cdots\end{array}$ & $\begin{array}{l}\text { Very little edema } \\
\text { No edema } \\
\text { After fat free diet } \\
\text { Very edematous }\end{array}$ \\
\hline 6 & $\begin{array}{r}7 / 4 / 21 \\
7 / 22 / 21 \\
12 / 3 / 21\end{array}$ & $\begin{array}{l}0.776 \\
0.860 \\
0.472\end{array}$ & $\begin{array}{l}1.6 \\
\ldots\end{array}$ & $\begin{array}{l}\text { Very edematous } \\
\text { Edema markedly diminished } \\
\text { Six months later no edema }\end{array}$ \\
\hline 7 & $\begin{array}{r}5 / 6 / 21 \\
6 / 23 / 21 \\
12 / 22 / 21\end{array}$ & $\begin{array}{l}0.452 \\
0.420 \\
0.254\end{array}$ & $\ldots$ & $\begin{array}{l}\text { Slight edema } \\
\text { Two weeks later no edema } \\
\text { No edema }\end{array}$ \\
\hline \multirow[t]{2}{*}{8} & $\begin{array}{l}3 / 12 / 21 \\
4 / 1 / 21\end{array}$ & $\begin{array}{l}0.314 \\
0.616\end{array}$ & $\cdots$ & $\begin{array}{l}\text { Comatose; blood } \mathrm{CO}_{2} 17 \text { (morphin) } \\
\text { Three weeks later, general condition good; non- } \\
\text { protein nitrogen decreased }\end{array}$ \\
\hline & $\begin{array}{r}4 / 26 / 21 \\
5 / 11 / 21 \\
11 / 19 / 21\end{array}$ & $\begin{array}{l}0.496 \\
0.418 \\
0.928\end{array}$ & $\cdots$ & $\begin{array}{l}\text { Marked diarrhea } \\
\text { Two weeks later, diarrhea stopped; edema gone } \\
\text { Six months later, no edema }\end{array}$ \\
\hline 9 & $\begin{array}{l}1 / 24 / 21 \\
3 / 9 / 21 \\
4 / 23 / 21 \\
5 / 10 / 21\end{array}$ & $\begin{array}{l}0.412 \\
0.276 \\
0.520 \\
0.516\end{array}$ & $\begin{array}{l}\cdots \\
\cdots \\
\cdots\end{array}$ & $\begin{array}{l}\text { Edema } \\
\text { Edema gone } \\
\text { Two weeks later, after being home, marked edema } \\
\text { Marked edema }\end{array}$ \\
\hline 10 & $\begin{array}{r}4 / 12 / 21 \\
5 / 28 / 21 \\
11 / 11 / 21\end{array}$ & $\begin{array}{l}0.464 \\
0.352 \\
0.366\end{array}$ & $\begin{array}{l}1.4 \\
\cdots \\
\cdots\end{array}$ & $\begin{array}{l}\text { Very edematous } \\
\text { Edema gone } \\
\text { Edema gone; still in hospital }\end{array}$ \\
\hline 11 & $\begin{array}{r}4 / 12 / 21 \\
3 / 28 / 21 \\
4 / 6 / 21 \\
11 / 15 / 21\end{array}$ & $\begin{array}{l}0.592 \\
0.696 \\
0.424 \\
0.376\end{array}$ & $\begin{array}{l}\cdots \\
\cdots \\
\cdots\end{array}$ & $\begin{array}{l}\text { General edema } \\
\text { General edema } \\
\text { Fdema almost gone } \\
\text { Slight puffiness of face }\end{array}$ \\
\hline 12 & $\begin{array}{l}3 / 31 / 21 \\
4 / 13 / 21 \\
7 / 19 / 21\end{array}$ & $\begin{array}{l}0.284 \\
0.170 \\
0.334\end{array}$ & $\begin{array}{l}0.9 \\
\cdots \\
\cdots\end{array}$ & $\begin{array}{l}\text { Marked edema } \\
\text { Fleven days after decapsulation, marked edema } \\
\text { Very edematous }\end{array}$ \\
\hline 13 & $10 / 27 / 21$ & 0.554 & $\ldots$ & General edema \\
\hline 14 & $\begin{array}{l}5 / 25 / 20 \\
7 / 6 / 20 \\
8 / 4 / 20\end{array}$ & $\begin{array}{l}0.460 \\
0.648 \\
0.430\end{array}$ & $\begin{array}{l}\cdots \\
\cdots\end{array}$ & $\begin{array}{l}\text { General edema } \\
\text { Marked edema } \\
\text { Edema still present }\end{array}$ \\
\hline 15 & $\begin{array}{l}3 / 9 / 19 \\
4 / 25 / 19 \\
6 / 1 / 19 \\
7 / 1 / 19 \\
8 / 11 / 19 \\
9 / 20 / 19\end{array}$ & $\begin{array}{l}0.488 \\
0.836 \\
0.738 \\
0.532 \\
0.616 \\
0.464\end{array}$ & $\begin{array}{l}\cdots \\
\cdots \\
\cdots \\
\cdots \\
\cdots\end{array}$ & $\begin{array}{l}\text { Fdema slight } \\
\text { No edema } \\
\text { Marked edema } \\
\text { Edema almost gone } \\
\text { Marked edema; condition poor } \\
\text { Marked edema }\end{array}$ \\
\hline 16 & $\begin{array}{l}5 / 9 / 21 \\
5 / 13 / 21 \\
6 / 25 / 21 \\
8 / 24 / 21\end{array}$ & $\begin{array}{l}0.376 \\
0.532 \\
0.388 \\
0.360\end{array}$ & $\begin{array}{l}\cdots \\
\cdots \\
\cdots\end{array}$ & $\begin{array}{l}\text { General edema } \\
\text { Marked edema; high protein diet begun } \\
\text { Fourteen days after decapsulation, still edematous } \\
\text { Still edematous }\end{array}$ \\
\hline 17 & $12 / 28 / 21$ & 0.740 & 1.7 & General edema \\
\hline
\end{tabular}

and the cause of the increase in the cholesterol and why it should accompany an increase of fat and lecithin is as yet unsolved.

From Table 8 it will be seen that in every one of our cases the cholesterol content of the blood was markedly increased, with the exception of Case 1. This estimation was not made when the patient was 
originally in the hospital, but only recently when she had been free from edema for some time, so that in this case we cannot make a definite diagnosis of nephrosis from the examination of the blood.

Case 4 is interesting for the child was markedly edematous at the time of the first blood examination. The cholesterol was 0.628 per cent. After losing all his edema, in fact, losing 29 pounds in weight, his cholesterol fell to 0.360 per cent. His serum protein and other nitrogen constituents of the blood were undisturbed. Again, in Case 6, when edema was present, cholesterol was 0.860 per cent., and six months later, without edema, it was 0.472 per cent. It would seem that there is some relationship between the edema and the amount of cholesterol in the blood, yet we have so many determinations to the contrary that this is apparently not the case. Thus, in Case 8, with edema, the cholesterol was 0.616 per cent. The child then had a diarrhea, the edema disappeared and the cholesterol went down to 0.36 per cent. Six months later, however, without marked edema during most of this time, the cholesterol had increased to 0.928 per cent.

Decapsulation of the kidney in two cases seemed to have a temporary effect on the amount of cholesterol in the blood.

In our experience we have found nothing which will directly reduce the amount of cholesterol in the blood for any length of time, be it food, thyroid or surgical procedure.

The total fat content of the blood was naturally high, for the total fat includes the lecithin, cholesterol and fatty acids. The determination of lecithin was impossible at the time because of some technical difficulty. The fat metabolism in the cases in which it was studied was apparently normal, although we did not determine the fat partitions in the stool. Feeding of fat or putting the patient on a fat free diet for a week at a time had no effect upon the cholesterol content of the blood.

Basal Metabolism.-Another interesting fact is the relationship of this hypercholesterolanemia to the suprarenal nad other ductless glands. We realize the interrelationship of these glands and discuss them with great reservation. It has been shown by Epstein and Lande ${ }^{36}$ in this Institution that the basal metabolism in these cases is much below the normal (Cases 4 and 5). They took into consideration the artificial increase in body weight in determining the metabolic rate. As these patients improve, the basal metabolism approaches nearer to the normal. Furthermore, the successful therapeutic use of thyroid by Eppinger, ${ }^{37}$ Epstein $^{7}$ and in some of our cases would point to a probable endocrine relationship. Epstein believes that the metabolism is always low when the cholesterol is high, and high when the cholesterol is reduced in

36. Epstein, A. A., and Lande, H.: (Personal communication).

37. Eppinger, H.: Pathologie u. Therapie des Menschlichen Odem., 1917. 
amount. Aub, Forman and Bright ${ }^{38}$ show that after suprarenalectomy in the cat the basal metabolism was low, but they gave no cholesterol figures.

\section{THE CAUSE CF EDEMA IN NEPHROSIS}

The cause of the edema has been the subject of investigation for many years. Many theories have been advanced to explain it. To the kidney, naturally, was ascribed the edema, for one observed so frequently oliguria with edema, and diuresis with the disappearance of the edema. All observers, however, now agree that the kidney is probably the least offending link in the chain of causes. This chain may tentatively be made up of (a) physical, biological or chemical change in the blood itself ; $(b)$ change in the walls of the capillaries; $(c)$ change in the physical or chemical composition of the tissue fluids; $(d)$ change in the walls of the venules or lymph channels; $(e)$ change in the body cells themselves; $(f)$ disturbance of the endocrine gland; $(g)$ abnormal nervous control; $(h)$ pathologic lesions of the kidney.

A discussion of each of these subjects would take us too far afield, and one may be so linked with the others that it is almost impossible to discuss them separately. Yet some of the newer work might be of interest.

The chemical composition of the blood is so changed that it is very tempting to lay the blame here. As shown before, the serum protein content is consistently diminished, yet this is not the case when edema occurs from some other cause. This decrease in blood protein is not necessarily due to a change in the blood volume and the presence of a hydremia. This was well illustrated in Case 4 . The serum protein content was 4.2 per cent. during general anarsaca. Within a week, a marked diuresis having taken place, the child lost 29 pounds in weight and all manifest edema had disappeared, yet the blood protein remained the same. It would not appear, therefore, that the reduction in the protein content of the blood is a great factor.

The sodium chlorid content of the blood did not vary much, never going above $6.1 \mathrm{mg}$. or below $5.1 \mathrm{mg}$. per 100 c.c. of blood, independent of the presence or absence of edema. These figures were obtained on a fasting stomach. Atchley ${ }^{39}$ showed that there may be no change in the sodium chlorid content of the blood plasma, independent of intake or urinary excretion and, paradoxical as it may seem, to the apparent chlorid balance.

Oehm ${ }^{40}$ has recently reported some interesting experiments in relation to the control of diuresis by means of the physical and chemical

38. Aug, J. C.; Forman, J., and Bright, E. M.: Am. J. Physiol. (Proc.) 58: 293,1921 .

39. Atchley, D. W.: Arch. Int. Med. 22:370 (Sept.) 1918.

40. Oehm, C.: Verhandl. des Congress f. inn. Med., 1920, p. 137. 
composition of the blood. He uses two sets of animals-one fed on a dry diet, and the other on a moist diet. During the experiment he repeatedly determined hemoglobin, the serum protein and the sodium chlorid. In both sets of animals the water from the blood goes into the tissue and carries along with it the protein. In the dry fed animals more water remained in the blood than in the moist fed animals, so that the blood was just as rapidly diluted. There is no hydremia in the case of moist fed animals to account for the diuresis which occurs. In tying off the kidneys in both sets of animals there is no difference in the chemical composition of the blood.

The high cholesterol content of the blood does not seem to have any relation to the transudation of fluid and the causation of edema, for, as we will show, there is little or no cholesterol permitted to go through the walls of the capillaries into the edema fluid. It is well known that there is a constant interchange of water, organic and inorganic substances, from the blood into the tissue spaces, thence to the cells and back to the tissue spaces. MacCallum ${ }^{41}$ showed that there was no direct connection between the lymph spaces and the tissue spaces and that the lymph channels ended in a blind pouch.

It is important, therefore, to differentiate between (a) transudate, (b) tissue fluids and (c) lymph fluids.

(a) Transudate is that fluid which goes through the walls of the capillaries. It may be normal or pathologic.

(b) Tissue fluids are that part of a transudate taken up by the cells and given off by the cells.

(c) Lymph is that fluid which flows out of the lymph channels. Fluids and other substances from the blood must pass through these tissue spaces before going to all the organs and returning to the blood.

After hemorrhage there is a marked flow of tissue fluid into the blood. This is not from the lymph for there is no demonstrable increase of lymph flow from the lymphatics. Conversely, after transfusion there is a flow of fluid towards the tissues.

Magnus ${ }^{42}$ found that 19 per cent. of fluid given intravenously had left the blood stream in three minutes and 50 per cent. had left it in twenty minutes. The injection of hypotonic salt solution causes an exodus of water into the tissues, and salt into the blood. The composition of the blood remains fairly constant. It seems to be the function of the walls of the capillaries to permit the exit or entrance of fluid and other substances into the blood stream, whenever the balance between blood and tissues is disturbed.

41. MacCallum, W. G.: Text Book of Pathology, 1916, p. 41. 1900.

42. Magnus, R.: Arch. f. exper. Patl. u. Pharmakol. 42:250, 1890: 44:68, 
Hooker, ${ }^{43}$ and more recently, Wallace and Pellini, ${ }^{44}$ have demonstrated specific capillary poisons which permit of great permeability and this way be the cause of graver general disturbances in the body. Some of these poisons have a selective action on capillaries of certain parts of the body as those of the liver. It is tempting to consider the cause of the disease we are describing as due to a capillary poison acting especially on the skin, muscle and perhaps kidney capillaries.

From the physicochemical standpoint Priestley ${ }^{45}$ thinks that the interchange of fluids may be due to a diminution in the electrical conductivity of the plasma, and a difference in what he calls the diffuse pressure. He has likened the blood to a gas, and has tried to explain the diffusion of fluids out of and into the blood stream by the same laws as govern gases. He defines the diffusion pressure of water on both sides of the membrane, as proportioned to the water molecules and the total molecules.

An analysis of the tissue fluids themselves might help to clear up the problem (Tab'e 9). Unfortunately, it is impossible to obtain fluid from the interstices of the tissues in the normal person. In various forms of edema, however, it is shown that these tissue fluids differ. Beckman, ${ }^{46}$ who has examined a great variety of edema fluids, has shown that the edema fluids in the nephrosis cases contain only 0.1 per cent. protein. In our cases it was never higher than 0.18 per cent. In the cardiac, the protein content was 0.4 per cent. and in the nephritic the protein content was often over 1 per cent. It will be seen, therefore, that in edema from various causes the vessel walls will differ as to their permeability to protein. Whether 0.1 per cent. protein, as occurs in nephrosis, is greater than the normal cannot be stated. It is this permeability of the vessel wall to protein that Eppinger ${ }^{37}$ called the albuminuria of the tissues and is a feature of all edema fluids.

The sodium chlorid content of the various edema fluids is about the same, 0.6 per cent. Thannhauser ${ }^{47}$ gave sodium chlorid to nephritics and found that the sodium chlorid of the edema fluid and the blood increased, but the latter, however, to a lesser extent. Soon, however, the sodium chlorid of the blood and edema fluid diminished rapidly, but there was no increase of the salt in the urine. Beckman ${ }^{46}$ believes that there is another depot for the salts which is probably the tissue cells.

The cholesterol content of the edema fluids is practically nil. Apparently, the capillary wall is impermeable to this substance.

43. Hooker, D. R.: Physiol. Rev. 1:112, 1921.

44. Wallace, G. B., and Pellini, E. J.: Arch. Int. Med. 28:711 (Dec.) 1921

45. Priestly, G. J.: J. Physiol. 55:306. 1921.

46. Beckman, K.: Deutsch. Arch. f. klin. Med. 135:39, 1921.

47. Thannhauser, S. J.: Ztschr. f. klin. Med. 89:181, 1920. 
The relation of the endocrine glands to edema has been emphasized by Eppinger in his monograph. Thevenat ${ }^{48}$ was the first to use thyroid as a diuretic. Soon afterward Eppinger began his studies of thyroid extract as an effective diuretic in edema and especially in the so-called nephrotic edema. The manner in which it works is not definitely known. He concluded that it had no specific action on the kidney. He has proven that water and salt are excreted more rapidly after the administration of thyroid. Under normal conditions salt given subcutaneously is excreted more rapidly than if given by mouth. In some abnormal conditions, especially in nephrosis, salt given subcutaneously is excreted less rapidly than that given by mouth. If thyroid is administered the patient will have an excretion which is normal or above normal. Hence,

TABle 9.-Analysis of Edema Fluids

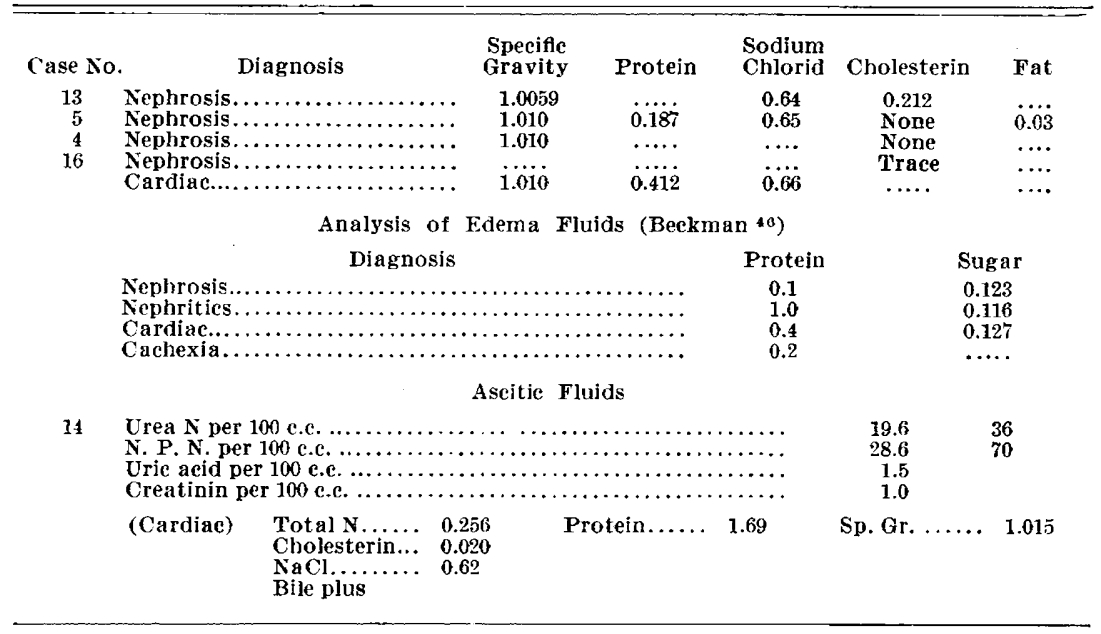

Eppinger believes that there is certainly no selective action on the kidney. Epstein ${ }^{36}$ believes that the thyroid increases the basal metabolism. The specific dynamic action of the protein is raised and the colloidal combination of protein in the tissue fluids is changed, thus perhaps setting free the water in the tissues. The hypophysis, on the other hand, has a direct action on the kidney (Oehm ${ }^{40}$ ).

Oehm has shown that there is a substance in the duodenal mucosa that has a diuretic action. He also thinks that products of metabolism simultaneously stimulate the tissues and the kidney.

That the central nervous system may have some control of the water excretion is shown in some of the intracranial diseases, notably in the disturbance of the hypophysis or tumors of the posterior fossa. The

48. Thevenat, L.: Progrès. méd., 1913, p. 237. 
experimental work of Veil ${ }^{49}$ and Leschkes, ${ }^{50}$ demonstrated that injury to the brain in the region of the fourth ventricle causes a polyuria with a hyperchlorinemia, whereas an injury to the midbrain produced polyuria but no hyperchlorinemia.

It has been known for a long time that section of the renal nerve to one kidney causes an increased flow of urine on that side. This is probably due to a circulatory disturbance in the kidney. E. K. Marshall and $\mathrm{A}$. C. Koll ${ }^{51}$ have confirmed this observation, but have also shown that identical results can be obtained by section of one splantic nerve to the suprarenal or removing one of the suprarenal glands.

From the foregoing it will be seen how complex is the problem of fluid excretion.

\section{WATER TEST}

In considering the many important and interesting facts already cited, and realizing the importance of the extra renal element, it must not be forgotten that the excretion of water by the kidney gives some very valuable information after all. Many functional kidney tests have been described, such as the excretion of dye stuffs, or salt, of urea and of water. We cannot go into a discussion as to the value of all these tests.

In the course of our work it appeared to us that the excretion of water alone or water with the addition of salt gave considerable information. The test could be carried out very easily and done at home without any difficulty. However, we were very careful with the salt in our nephrosis cases, so that we finally confined ourselves to the administration of water alone. For a long time it has been known that water ingested by a normal person is excreted in a fairly regular manner. This fact was first made use of by Koryani, ${ }^{52}$ later amplified by Strauss ${ }^{53}$ and finally modified by Volhard. ${ }^{1}$ The test for adults is described by Volhard as follows:

After the usual evening meal the patient is kept in bed for the following one and a half days. At $8 \mathrm{a} . \mathrm{m}$. the patient empties the bladder and this urine is discarded. Immediately after, an adult is given $1 \frac{1}{2}$ liters of ordinary water which is swallowed as quickly as possible. No breakfast is given. The patient is asked to urinate every half hour for the next four hours. These specimens are kept separately for further examination. At the end of the four hours, a dry meal is given, such as meat, thick cereal and bread. But no additional fluid of any kind is permitted until the next morning at 8 o'clock. At $6 \mathrm{p} . \mathrm{m}$. another such fiuid free meal is permitted. After the first four hours (from $8: 30$ a. $\mathrm{m}$. to $12: 30 \mathrm{p} . \mathrm{m}$.) the patient urinates whenever desired, keeping each specimen separately, the final specimen being collected at 8 a. m., which completes a twenty-four hour cycle. This specimen is preserved. The specimens are examined as to volume and specific gravity.

49. Veil, W. H.: Verhandl. d. Congr. f. inn. Med. 32:134, 1920.

50. Leschkes, E.: Ztschr. f. klin. Med. 87:201, 1919.

51. Marshall, E. K., and Koll, A. C.: Am. J. Physiol. 49:302, 1919.

52. Von Koryani, A.: Physic. Chem. u. Medizin. 2:133, 1908.

53. Strauss, H.: Chronische Nierenentzündung, Berlin, 1902. 
It will be seen from the chart that in the normal cases almost the entire fluid ingested will be excreted within the first four hours. The first specimen voided is small in amount, then the volume increases rapidly until the end of the fourth specimen when it begins to drop to a relatively low figure. The specific gravity follows the volumetric change very closely, the urine becoming more and more diluted, the specinc gravity often being as low as 1.001 at the end of the third specimen, then it gradually increases so that the specific gravity in the last specimen may be between 1.030 and 1.040 .

Of course, in children the amount of water given must be considered. Aschenheim, ${ }^{54}$ Stransky and Belant ${ }^{55}$ have investigated the use of this test in infants, and Ohlman ${ }^{56}$ in older children. We have

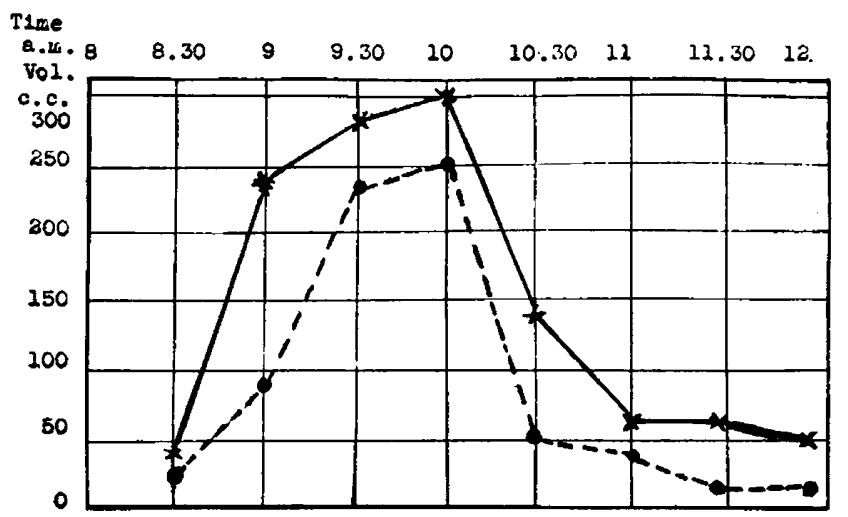

Results of water test; intake, 900 c.c. Amount excreted every thirty minutes for the first four hours. $\times \longrightarrow \times$, normal; $\bullet----\bullet$, case of nephrosis.

appended a chart taken from Ohlman ${ }^{56}$ which is, however, in the form of percentage intake excreted in twenty-four hours.

The amount of water excreted depends on the age of the child; the younger the child the more water is retained. In a general way it may be said that a normal patient should excrete about the amount ingested at the end of four hours. Of course, this excretion depends somewhat on atmospheric temperature and the activity of the person. The fluid lost by respiration is fairly constant. The addition of salt to the water has a marked effect. The diuresis sets in a little sooner but the total quantity excreted is considerably lower. One other fact must be considered during this test. A person who has been on a dry diet, or a diet comparatively poor in water, will have a much diminished excretion as compared with one who has been on a normal amount of water

54. Aschenheim, E.: Ztschr. f. Kinderh. 24:281, 1920.

55. Stransky, E., and Balint, A.: Jahrb. f. Kinderh. 93:350, 1920.

56. Ohlman, J.: Ztschr. f. Kinderh. 26:296, 1920. 
previous to the inauguration of the test. It is important, therefore, to have the amount of fluid to be ingested on the test day about equal to the amount usually taken by the patient.

We must bear in mind from the work of Priestley ${ }^{45}$ that the kidney has optimum excretory power per certain unit of time. ${ }^{57} \mathrm{He}$ gave larger amounts of water to normal persons hour after hour and found that the kidney would not or could not excrete more than a certain amount in a given period of time. Priestley does not believe that there is any great relation between the water and the salt excretion. After drinking 2 liters of water there is a transitory increase in the absolute

TABLE 10.--Normal Water Test-940 C.c.

\begin{tabular}{|c|c|c|}
\hline Time & Volume, C.c. & Specifte Gravity \\
\hline 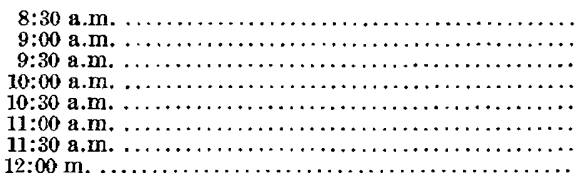 & $\begin{array}{r}40 \\
240 \\
290 \\
300 \\
140 \\
60 \\
60 \\
50\end{array}$ & $\begin{array}{l}1.010 \\
1.004 \\
1.008 \\
1.008 \\
1.008 \\
1.010 \\
1.012 \\
1.014\end{array}$ \\
\hline 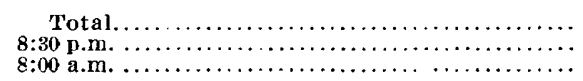 & $\begin{array}{r}1,180 \\
430 \\
140\end{array}$ & $\begin{array}{l}1.030 \\
1.040\end{array}$ \\
\hline Full total $\ldots \ldots \ldots \ldots \ldots \ldots \ldots \ldots \ldots \ldots \ldots \ldots$ & 1,750 & \\
\hline
\end{tabular}

Table 11.-Water Test in Normal Children (From Ohlman) ${ }^{\text {g6 }}$

\begin{tabular}{|c|c|c|c|}
\hline Age & $\begin{array}{c}\text { Water Intake, } \\
\text { C.c. }\end{array}$ & $\begin{array}{c}\text { Exeretion } \\
\text { in } 5 \text { Hours, \% }\end{array}$ & $\begin{array}{l}\text { Exeretion in } 5 \text { Hours } \\
\text { if } 0.7 \text { per Cent. } \\
\text { Salt is Added, } \%\end{array}$ \\
\hline 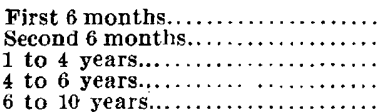 & $\begin{array}{l}100 \\
200 \\
300 \\
400 \\
\text { 100 }\end{array}$ & $\begin{array}{l}60 \text { to } 80 \\
80 \text { to } 90 \\
91 \\
133 \\
175\end{array}$ & $\begin{array}{l}27 \text { to } 43 \\
49 \text { to } 70 \\
70 \\
87 \\
107\end{array}$ \\
\hline
\end{tabular}

amount of chlorid excreted per hour. This washing out, however, lasts only a very short time and a normal chlorid excretion is resumed even though diuresis is increasing.

This water test was used in nine of the reported cases; sometimes only once, other times more frequently. We were careful not to use this test during a period of diminishing edema and only when the condition of the child had been fairly constant for a few days. In judging the amount of water to be given we considered the age of the patient and the amount of urine he was excreting for a few days previously, although always bearing in mind the fact that during the previous days the fluid had not been given all at one time but distributed throughout the day and that food was also given at various times of the day. These facts undoubtedly affect the water excretion.

57. Priestley, J. G., and Haldane, J. S.: J. Physiol. 50:296, 1916. 


\section{RESULTS OF WATER TEST}

CASE 1.-A child, aged 11 (Case 5), had very little edema at the time the test was made. Weight, 70 pounds.

The excretion increased rapidly for the first one and one-half hours and then receded rapidly. He did not excrete the entire 1,000 c.c. during the first four hours but did at the end of the twenty-four hours. This retardation we have found to occur frequently in these cases of nephrosis.

A second test, made two and one-half months later, when he was very edematous (weight, 95 pounds), showed much the same characteristics. His diuretic curve was normal. He excreted 500 c.c. of the total in the first four hours, 100 c.c. more than the intake in the twenty-four hours. Only $2 \mathrm{gm}$. sodium chlorid was excreted during the entire day.

CASE 2.--A child, aged 7 years (Case 4), very edematous, weight being about the same two days before and after the test. On an intake of 500 c.c. he only excreted 250 c.c. Given a water test of 500 c.c. a marked diuretic effect was seen. Why in some instances the ingestion of large quantities of water causes a diuresis at one time and not at others cannot be explained.

TABLE 12.-Water Test: Case 1 (5), 1,000 C.c.

\begin{tabular}{|c|c|c|}
\hline Time & Volume, C.c. & Specific Gravity \\
\hline 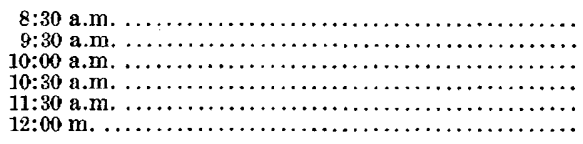 & $\begin{array}{r}50 \\
150 \\
200 \\
200 \\
25 \\
30\end{array}$ & $\begin{array}{l}1.006 \\
1.002 \\
1.001 \\
1.001 \\
1.004 \\
1.008\end{array}$ \\
\hline 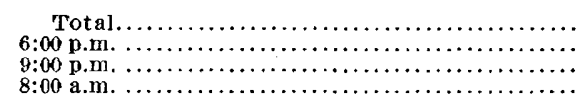 & $\begin{array}{r}695 \\
130 \\
70 \\
220\end{array}$ & $\begin{array}{l}1.022 \\
1.022 \\
1.022\end{array}$ \\
\hline
\end{tabular}

TABLE 13.-Water Tests Case 2 (4), 500 C.c.

\begin{tabular}{|c|c|c|}
\hline Time & Volume, C.c. & Specific Gravity \\
\hline $8: 30$ a.m. $\ldots \ldots \ldots \ldots \ldots \ldots \ldots \ldots \ldots \ldots \ldots \ldots \ldots \ldots$ & 145 & 1.024 \\
\hline 9:00 a.m. & 30 & 1.004 \\
\hline 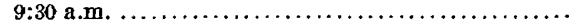 & 80 & 1.003 \\
\hline 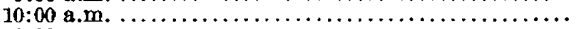 & 13 & 1.005 \\
\hline 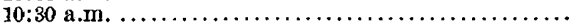 & 10 & 1.010 \\
\hline 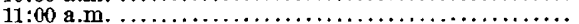 & 10 & 1.012 \\
\hline 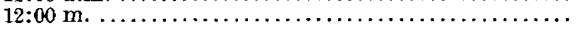 & 10 & 1.020 \\
\hline
\end{tabular}

CASE 3.-A child, aged 10 years (Case 7), excreted from 300 to 400 c.c. in twenty-four hours for previous few days. It was given 600 c.c. in the water test.

Table 14 shows a normal character to the excretion but a diminished output-357 c.c. of the 600 c.c. excreted in the first four hours ; 500 c.c. in twentyfour hours.

CASE 4.-Child aged 4 years (Case 8), with moderate edema. Although the total excretion is good the specific gravity never went above 1.018.

CASE 5.-Child, aged $5 \frac{1}{2}$ years (Case 11 ), with moderate edema. The first water test was followed by a marked diuresis. One month later, the boy, being in about the same condition, was given 500 c.c. but only excreted 250 c.c. in the first four hours and 326 c.c. in the twenty-four hours. We are unable to explain this difference. The concentration in both specimens was normal.

CASE 6.-A child, aged 5 years (Case 14), had been edematous for a long time, the weight changing but little. From Table 16 it will be seen that the excretory curve is a little different from that of other cases. The diuresis continued for a longer period and no single specimen contained more than 100 c.c. Either the water was not brought to the kidney to be excreted, or the kidney did not have the power to eliminate the fluid. 
In conclusion, it is quite evident that the manner in which the water is excreted in this type of case in most instances approaches very close to the normal. At times the total quantity excreted is not quite up to the normal. It seems remarkable that an individual with such marked edema should, when given large quantities of water, excrete most of it in a short time; very little is retained, showing well that the excretory power of the kidney is not diminished. Either this water goes directly

Table 14.-Water Test: Case 3 (7), 600 C.c.

\begin{tabular}{|c|c|c|}
\hline Time & Volume, C.c. & Specific Gravity \\
\hline 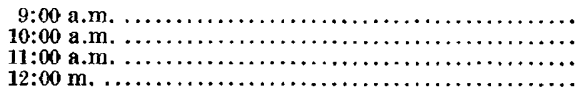 & $\begin{array}{r}125 \\
162 \\
20 \\
50\end{array}$ & $\begin{array}{l}1.004 \\
1.001 \\
1.004 \\
1.007\end{array}$ \\
\hline 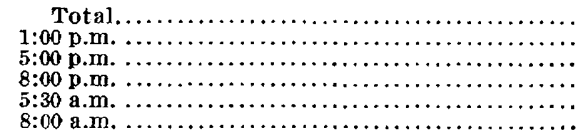 & $\begin{array}{r}357 \\
20 \\
46 \\
22 \\
31 \\
19\end{array}$ & $\begin{array}{l}1.010 \\
1.024 \\
1.028 \\
1.024 \\
1.024\end{array}$ \\
\hline
\end{tabular}

TABle 15.-Water Test: Case 4 (8), 800 C.c.

\begin{tabular}{|c|c|c|}
\hline Time & Volume, C.c. & Specifle Gravity \\
\hline 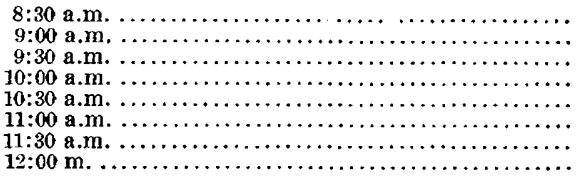 & $\begin{array}{r}57 \\
145 \\
153 \\
165 \\
130 \\
45 \\
27 \\
27\end{array}$ & $\begin{array}{l}1.010 \\
1.012 \\
1.002 \\
1.002 \\
1.002 \\
1.002 \\
1.010 \\
1.006\end{array}$ \\
\hline 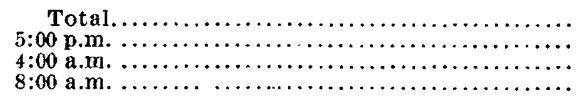 & $\begin{array}{r}749 \\
45 \\
105 \\
40\end{array}$ & $\begin{array}{l}1016 \\
1.018 \\
1.014\end{array}$ \\
\hline
\end{tabular}

Table 16.-Water Test: Case 6 (14), 600 C.c.

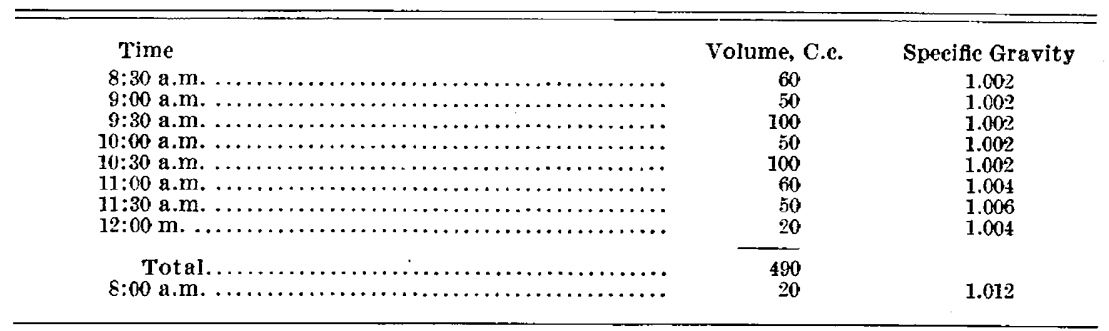

into the tissues and other fluid is brought to the kidney, or this water goes directly to the kidney, the tissues being so saturated that they do not take up any more fluid.

Urine.-The ordinary chemical and microscopic examination of the urine in this class of case is so well known that one need not go into detail; the usual high specific gravity and the intense albuminuria with comparatively few casts is the common feature. Red blood cells are 
occasionally found. Even with a concomitant acute infection, hematuria is not usually present. Funk was the first to find double refractory bodies in the urine. Gluck found these lipoid bodies to be present after giving cholesterin.

Nitrogen excretion is normal. Using a modified Mosenthal diet, in no case was there ever a real nitrogen retention. Sodium chlorid excretion, however, was affected. The sodium chlorid excretion in the urine was almost nil during the edematous stage. During diuresis as much as $25 \mathrm{gm}$. sodium chlorid was excreted in twenty-four hours. In this latter case the concentration of the sodium chlorid was 0.6 per cent. in a volume of 4,000 c.c.

Complications.-The complications seen in this disease are all due to the diminished immunity which these patients seemed to have for the acute infection. Those involving the skin, such as erysipelas, seem to

TABLE 17.-Duration and Prognosis

\begin{tabular}{|c|c|c|c|c|}
\hline Case No. & First Seen & Last Seen & Duration & Condition When Last Seen \\
\hline 1 & August, 1919 & December, 1921 & 2 yrs. 3 mos. & $\begin{array}{l}\text { Albumin }++ \text {; no edema; gen. } \\
\text { eral condition good }\end{array}$ \\
\hline 2 & February, 1919 & May, 1919 & 5 mont hs & Dead; pneumonia \\
\hline 3 & 1915 & July, 1919 & 4 years & Dead; uremia (?) \\
\hline 4 & September, 1921 & Jan. 16, 1921 & 4 months & Condition good; no edema \\
\hline 5 & Sentember, 1921 & Jan. 14,1922 & 4 months & Dead; pneumococ. peritonitis \\
\hline 6 & July, 1921 & December, 1921 & 6 months & Urine, albumin ++ ; no edema \\
\hline 7 & January, 1921 & January, 1922 & 1 year & Urine, albumin ++ ; no edema \\
\hline 8 & July, 1920 & December, 1921 & $1 \frac{1}{2}$ years & $\begin{array}{l}\text { Urine, albumin }++; \text { slight } \\
\text { edema }\end{array}$ \\
\hline 9 & July, 1920 & December, 1921 & $11 / 2$ years & $\begin{array}{l}\text { Urine, albumin }++ \text {; no edema; } \\
\text { in hospital }\end{array}$ \\
\hline 10 & April, 1920 & December, 1921 & $13 / 4$ years & $\begin{array}{l}\text { Urine, albumin }++; \text { slight } \\
\text { edema; in hospital }\end{array}$ \\
\hline 11 & August, 1920 & December, 1921 & 17 months & $\begin{array}{l}\text { Urine, albumin }+; \text { slight } \\
\text { edema; cholesterin } 0.376 \%\end{array}$ \\
\hline 12 & June, 1920 & December, 1921 & 18 months & $\begin{array}{l}\text { Albumin }++; \text { slight edema; } \\
\text { in hospital }\end{array}$ \\
\hline 13 & October, 1921 & December, 1921 & 2 months & Very marked edema \\
\hline 14 & Mareh, 1920 & January, 1921 & 10 months & Dead; diphtheria \\
\hline 15 & January, 1919 & July, 1921 & $1 / 2$ year & Dead; pneumonia (?) \\
\hline 16 & March, 1921 & November, 1921 & 8 months & Dead; nephrosis \\
\hline 17 & November, 1921 & January, 1922 & 2 months & Dead; pneumococ. peritonitis \\
\hline
\end{tabular}

be less frequent than similar cases in the adult. One patient died of a complicating diphtheria. Although discovered early, and large doses of antitoxin being given, the membrane spread with remarkable rapidity.

Pneumococcus infection seems especially virulent in every case. When the patient complains of abdominal pain one would always have in mind a pneumococcus peritonitis. Two of our patients (Cases 5 and 17) died of this complication. Two died of pneumonia. True uremia, in the sense of a stupor associated with an increasing nitrogen retention, is rarely seen. When coma supervenes it is not associated with a nitrogen retention and is usually of short duration. It may best be thought of as a temporary cerebral edema.

Prognosis.-From our experience the prognosis of these cases as to life is bad. Six of the seventeen patients died, and none of the 
others can be declared well, although some have been observed for more than three years. Of the fatal cases, the duration of one case was two months and another four years. This latter case had a fairly constant edema. Death usually occurs from some intercurrent infection, although one child seemed to die of uremia. Table 17 gives a good idea of the present status of our cases. We hope to give a more detailed picture of the prognosis at some future date. We are continuing our observations on ten of the cases here reported.

Treatment.-In a condition such as this with its chronicity and marked periods of apparent improvement occurring without any definite cause, one must be very cautious in ascribing great value to any one special procedure. In the present state of our knowledge, prevention can hardly be considered. We feel sure that tonsillectomy and the removal of other foci play but a small rôle in the care of these children, except, perhaps, to put them in the best possible conclition. As stated before, these children are not usually of the lymphatic type.

The treatment of the disease must necessarily be directed to $(a)$ the albuminuria; $(b)$ the pathologic changes in the blood, and $(c)$ the edema and the oliguria. From our observations we can say that we have been unsuccessful in permanently affecting the albuminuria or the cholesterinemia. Although at times the albuminuria would be less, at other times, while on the same method of treatment, there would be a marked increase in the albuminuria. The casts in the urine would be present or absent for weeks at a time, without any indication of a real benefit to the patients or foretelling a relapse of the symptoms (edema). The high cholesterin in the blood seemed never permanently affected by whatever method of treatment, and at times when all, or nearly all, manifest edema had disappeared the cholesterin values were highest.

There remains, then, the treatment of the edema and, coincidentally. of the oliguria. This has for years been attacked by means of diet, drugs or both. In addition operative procedures have also been employed. The elimination of fluids from the body is the prime object and the many theories by which this may possibly be accomplished have been treated of in previous portions of this article. Practically, we may consider first the restriction of water in the diet. We have tried this in many cases and systematically have given about the amount eliminated by the kidney for a few days previously, or even reduced the amount to a very small fraction of the kidney excretion but have found that this does not cause an elimination of the body fluids and the edema remains. In fact, we have found that the ingestion of large amounts of water within a short period of time, as in the water test, has a marked diuretic effect and the regular administration of this diuretic water shock has been suggested by Dorner ${ }^{58}$ and used in some of our

58. Dorner, G.: Med. Klin. 17:45, 1921. 
cases. At the present writing, it is our opinion that almost the normal amount of water according to age can be given to these cases without any harm. The Karrel treatment has been tried and the amount of milk given was considerably less than the amount of fluid according to the age. In some cases this would cause a dimunition of the edema, while in others it had absolutely no effect. Indeed, in the same case it would be effectual at one time, and ineffectual at another. Epstein ${ }^{59}$ seems to think that these are different types of the disease, yet when this occurs in the same case, there must be another explanation. It seemed to us that whenever the small amount of salt present in the milk was really an overdose, the edema was unaffected. In regard to other articles of food in these cases, there have been many conflicting opinions. From our observation we can definitely say that only one constituent of diet seems to do harm, and that is the salt. We have seen considerable carbohydrate given, without much effect upon the edema and no change in the chemical composition of the blood. This is also the case with fat and protein.

The administration of protein, in whatever form, has no deleterious effect on the general condition, the edema or the chemical composition of the blood. This brings us to a discussion of excessive amounts of protein in the diet as recommended by Epstein. ${ }^{7}$ There can be no doubt that his high protein diet does good in many cases, and it has seemed to us especially in those cases where the patient has been on a very low protein diet previously. It would appear that this is another example of treating the child as a whole; not letting his general condition deteriorate by a very onesided diet, especially in so important a principle as protein. Epstein's explanation of the edema being due to a dimunition of a blood protein caused by excretion of albumin in the urine does not seem to be proven, for in the first place it has been shown by Nonnenbruch ${ }^{17}$ that the serum protein of the blood has little to do with the egress of water from the capillaries into the tissues. In the second place, in some of our cases in which we have given large amounts of protein over periods of months, the edema may or may not have disappeared, yet the serum protein of the blood still remains low. The relationship of globulin to the albumin in the blood serum, to which Epstein has drawn attention, we cannot discuss for we have no experience in observing this. As far as our experience with diet in this disease is concerned, it seems that it is best combated by placing the child on a fairly adequate amount of water, an absolutely salt free but normally balanced diet as far as the remainder of the food principles is concerned. Whether it is necessary to give added amounts of protein to make up for the loss in the urine we cannot definitely say for we are

59. Personal communication. 
studying this phase of the disease. That large amounts of protein in the food tend to raise the protein in the blood does not seem to be the case.

As far as the treatment of the edema by means of the ordinary diuretics is concerned it can be fairly definitely stated that they are of no avail, and the saline diuretics may be of decided harm. We have used theocin for its supposed direct action on the kidney and have had no beneficial results. The use of thyroid, however, seems to raise the basal metabolism in these cases and in many instances has a miraculous effect on the edema. We have taken the suggestion of Epstein and Lande, ${ }^{36}$ have begun with small doses of thyroid and controlled the increase by basal metabolism observations.

Decapsulation was tried in two of our cases with very little or no effect on the edema, the blood chemistry or the general condition. We are aware that in the literature there are a sufficient number of cases published to warrant this procedure, although in our series the result has been nil.

To sum up, then, our treatment of these patients is to keep them in bed while they have any manifest edema, place them in the best hygienic surroundings, on an absolutely salt free diet, with a normal amount of fat and carbohydrate and an amount of protein somewhat in excess of the normal; a fluid intake almost that of the normal. If this does not suffice, we have added thyroid extract in increasing amounts. As far as the cure of the disease is concerned, the reduction of the albumin in the urine, the cholesterin and fat in the blood, this we have been unable to accomplish.

\section{REPORT OF CASES *}

Case 5 (Hospital No. 213050).-Male, aged 11, admitted Sept. 1, 1921. The child had had recurrent edema of about three months' duration, apparently caused by nasopharyngeal infection, but never any hematuria. However, a history of scarlet fever some years previously might point to the nasopharyngeal infection as a cause for a relighting of an old infection of the kidneys, although there were no symptoms in the interim, as far as the history can elucidate. From the chemical examination of the blood for a period of two months, the low blood pressure, high cholesterin, and the recurrent edema, it would seem that this is a case of nephrosis. Thyroid was given beginning with $3 / 4$ grain three times a day, gradually increased to 3 grains three times a day. During this time the edema remained about the same and the basal metabolism had not been accelerated, remaining between -20 and -30 per cent. The child did not respond to treatment, although at one time or other on a salt-free diet, a fat-free diet and, for the past two months, on a high protein diet. Whether this condition was of only a few months standing or whether it dated from the scarlet fever, seven years ago, is impossible to state definitely. The child died of lobar pneumonia.

Family History.-Negative.

Previous History.-Measles (time unknown); scarlet fever seven years ago, but no evidence of kidney disease at that time.

* These cases have been selected as illustrating special points made in the text. All the cases studied will appear in the reprints. 
Present History.-Just before the present illness, the child had difficulty in swallowing and was told that he had tonsillitis. A week later (six weeks ago) his mother noticed that he had swelling of arms and legs. After three weeks the swelling disappeared entirely. Was out of bed one week when the edema reappeared. He had no nocturia, hematuria or polyuria. His appetite was good and he had no fever.

Physical Examination.-The child was well developed, fairly well nourished. Face: edematous; some enlargement of cervical lymph glands. Heart: apex beat in fifth space and nipple line; second aortic sound exceeds that of the second pulmonic in intensity; faint systolic murmur at apex. Abdomen: shifting dulness. Extremities: some edema of feet.

Laboratory Examination.-Sept. 1, 1921: Hemoglobin, 78 per cent.; erythrocytes, 2,420,000; leukocytes, 10,000 ; polymorphonuclears, 68 per cent.

Pirquet and Wassermann Tests: negative.

Urine: acid; specific gravity, 1.020 ; albumin, trace; many hyaline and granular casts.

Blood Pressure: 105/75.

Blood Chemistry: Urea nitrogen, 11.2 ; nonprotein nitrogen, 37.5 ; uric acid, 2.5 ; creatinin, 1.3 ; cholesterin, 0.474 .

The excretion in four hours is fairly good. The amount of the twenty-four hour period is above that of the intake. The concentration is good.

TABLE 21.-URinary Excretion in CASE 5

September 5: Water Test, 1,000 c.c.

\begin{tabular}{|c|c|c|}
\hline 'Time & $\begin{array}{l}\text { Volume, } \\
\text { C.c. }\end{array}$ & $\begin{array}{l}\text { Specific } \\
\text { Gravity }\end{array}$ \\
\hline $8: 30$ a. $m . \ldots \ldots \ldots \ldots \ldots \ldots \ldots \ldots \ldots \ldots \ldots \ldots \ldots$ & 50 & 1.006 \\
\hline $9: 30$ a. m. .. & 150 & 1.002 \\
\hline 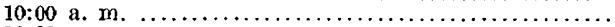 & 200 & 1.001 \\
\hline 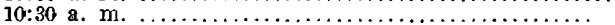 & 200 & 1.001 \\
\hline $11: 30$ a. m. ......... & 25 & 1.004 \\
\hline 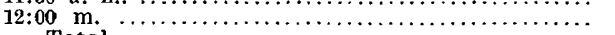 & 50 & 1.008 \\
\hline$\cdots \cdots \cdots \cdots \cdots \cdots \cdots \cdots$ & $-\frac{C 95}{130}$ & 1009 \\
\hline (n. & 130 & 1.022 \\
\hline $8: 00$ a. $m$. & 220 & 1.022 \\
\hline
\end{tabular}

September 6: Intake, 625 c.c.; excretion, 460 c.c. Weight, 82 pounds and 9 ounces. Fundi, negative.

September 7: On a salt-free diet; fluid limited to 800 c.c.

September 9: Temperature suddenly went up to $104 \mathrm{~F}$.; came down to normal next day, without any apparent cause.

September 12: Edema is very much diminished and the weight has dropped to 78 pounds. Child has been vomiting all day; continued vomiting for two or three days. All food has been excluded and Delafield's mixture given.

September 15: Intake, 700 c.c.; excretion, 600 c.c. Weight, 77 pounds and 14 ounces.

Septembet 17: Thick cereal, eggs and toast added to diet.

Blood Chemistry: Urea nitrogen, 11.2 ; nonprotein nitrogen, 35 ; uric acid, 3.4 ; creatinin, 1.8 ; cholesterin, 0.450 per cent.

For one week child was put on a fat-free diet and the cholesterin again estimated; the results showed no diminution, rather an increase in the cholesterin of the blood. Cholesterin, 0.592 per cent.

Basal Metabolism: - 20 per cent. below normal. Fat in blood serum, 1.2 per cent.

September 28: Blood pressure, 90/70. Patient is out of bed.

October 1: Intake, 700 c.c.; excretion, 650 c.c. Weight, 77 pounds and 4 ounces.

October 2: Nephritic Test Meal (Mosenthal) : Water retention, -+47 c.c. ; nitrogen retention, $-0.1 \mathrm{gm}$.; sodium chlorid retention, $-0.69 \mathrm{gm}$.

October 4: After being out of bed for a few days edema returned. 
October 7: Still has edema. Urine about the same since admission. Albumin, three plus; hyaline and granular casts; no erythrocytes or leukocytes. October 26: Phenolsulphonephthalein test, intramuscular: first hour, 25 c.c. (10 per cent.) ; second hour, 50 c.c. (15 per cent.) ; total. 25 per cent.

October 27: Phenolsulphonephthalein test, intramuscular: first hour, 50 c.c.

(17 per cent.) ; second hour, 100 c.c. ( 15 per cent.); total, 32 per cent.

November 9: On high protein diet.

November 21: Blood pressure, 100/70. Edema and weight about the same. November 25: Water Test.

November 18: Blood Chemistry: Urea nitrogen, 12; cholesterin, 1.552 per cent.; serum protein, 5.58 per cent.; cells, 30 per cent.; plasma, 70 per cent. December 7: Basal metabolism, -23 per cent.

December 12: Edema Fluid: Protein, 0.188; specific gravity, 1.010; cholesterin, none; fat, 0.03 ; sodium chlorid, 0.65 .

December 26: Weight, 83 pounds and 13 ounces.

Jan. 10, 1922: For the past four or five days child has been running a temperature with marked abdominal pain. Leukocytes, 23,000 ; polymorphonuclears, 94 per cent. Signs of pneumonia at the right base with a pneumococcus peritonitis.

January 14: Child died. No necropsy obtained.

CASE 8 (Hospital No. 208603).-Male, aged 4, admitted March 12, 1921. During his stay in the hospital had considerable abdominal pain and pain on

Table 22.-Urinary Excretion After Water Test in Case 5

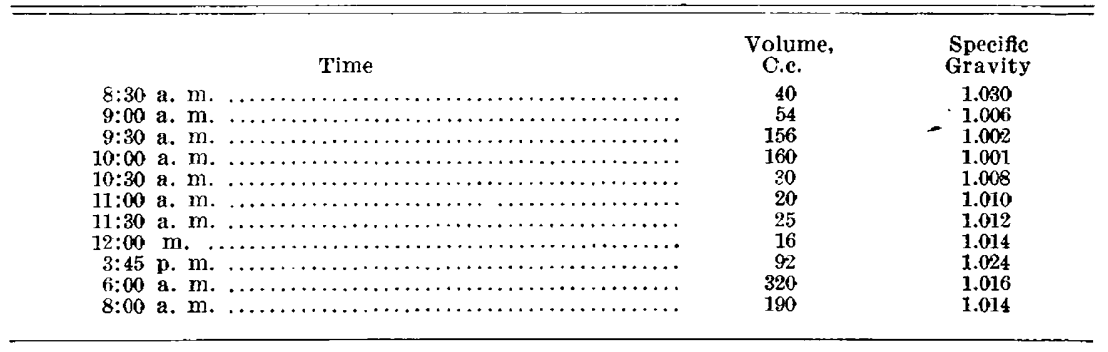

urinating. Urine, smoky and containing considerable blood. No explanation for the pain. The roentgenograms were negative. The chemistry of the blood showed an increase of nitrogen retention, increase in cholesterin and a marked diminution in carbon dioxid content; this latter due perhaps to the administration of morphin just before admission. While in the hospital he gradually acquired ascites and general edema; then a very severe colitis with mucus and blood in the stools, lasting several weeks. During this time edema and ascites disappeared. When colitis stopped edema reappeared. Finally discharged, June 14, in good general condition; albumin and casts in the urine; increased cholesterin in the blood, but no retention of nitrogen. When reexamined six months later the child was free from edema; urine contained albumin; blood almost 1 per per cent. cholesterin.

Fanily History.-Negative.

Previous History.-Measles in infancy; tonsillitis and scarlet fever (?) one year ago. No sore throat since.

Present History.-Eight months ago, about four months after the questionable scarlet fever, child's face became swollen, followed by general anasarca. Abdomen tapped. During this time vomited almost every day. After a few weeks the edema disappeared to reappear subsequently two or three times. Two and one-half months ago severe pain in the right side with a temperature of $106 \mathrm{~F}$. Anuria of one day's duration. Following this the urine was bloody for several weeks, and for weeks still had casts in the urine. Six weeks ago blood reappeared and intermittent hematuria has been present ever since. Two 
days ago child again had sudden pain in the right side with high temperature and anuria. A discharge from the right ear has persisted for the past six weeks.

Physical Examination.-The boy was semistuporous, face puffy and breath uremic. Tonsils: hypertrophied. Tight ear discharging. Heart, negative. No edema of the body or extremities. Catheterized specimen, 420 c.c. Phlebotomy, 100 c.c. Blood pressure, 100/70. Urine, smoky; albumin, two plus. Many erythrocytes and hyaline and granular casts.

Laboratory Examination-March 12: Leukocytes, 16,000; polymorphonuclears, 75 per cent.; hemoglobin, 57 per cent.; erythrocytes, 3,000,000.

Blood Chemistry: Nonprotein nitrogen, 87.5; uric acid, 4; creatinin, 2.4 ; carbon dioxid, 17.6 ; cholesterin, 0.314 per cent.

Temperature, $102 \mathrm{~F}$. Wassermann test, negative.

The semistuporous condition may have been due to the uremic poisoning as there is considerable nitrogen retention. On the other hand there is a very low carbon dioxid content which may point to an acidosis. Yet this might be due to a dose of morphin given just before admission. Child was put on 800 c.c. of 10 per cent. glucose water.

March 14: During the past few days patient's general condition is slightly improved but he complains of abdominal pain and pain on voiding. This latter may be due to the catheterization which was necessary.

Table 23.-Urine Excretion in Case 8 After Water Test

\begin{tabular}{|c|c|c|}
\hline Time & $\begin{array}{l}\text { Volume, } \\
\text { C.c. }\end{array}$ & $\begin{array}{l}\text { Specifle } \\
\text { Gravity }\end{array}$ \\
\hline 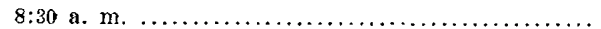 & 57 & 1,010 \\
\hline 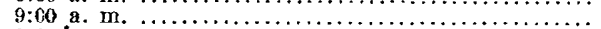 & 145 & $100 ?$ \\
\hline 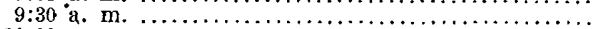 & 153 & $1.00 \%$ \\
\hline $10: 00$ a. m. & 165 & 1.002 \\
\hline 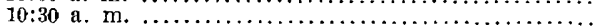 & 130 & 1.002 \\
\hline 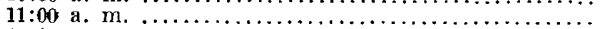 & 45 & 1.002 \\
\hline 11:30 a. m. & $2 \pi$ & 1.010 \\
\hline 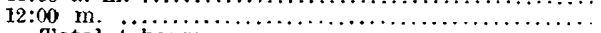 & 27 & 1.006 \\
\hline 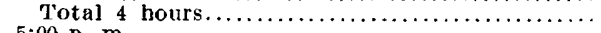 & -749 & \\
\hline 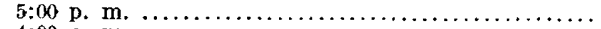 & 45 & 1.016 \\
\hline 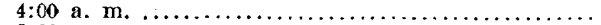 & 105 & 1.018 \\
\hline 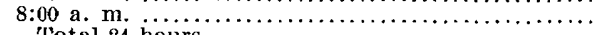 & 40 & 1.014 \\
\hline 'Total 24 hours $\ldots \ldots \ldots \ldots \ldots \ldots \ldots \ldots \ldots \ldots \ldots$ & $-1,009$ & \\
\hline
\end{tabular}

March 17: Sensorium is clear. Blood carbon dioxid, 29.4. Roentgen-ray examination of the kidney region is negative. The phenolsulphonephthalein excretion is 20 per cent.

March 27: Patient's general condition is excellent. On a diet of cereal, toast, spaghetti, fruit, green peas, baked potato and 450 c.c. of fluid consisting of milk only. Thus has a relatively high carbohydrate diet with moderate amount of protein in the form of vegetable and milk protein.

March 30: A water test of 800 c.c. of fluid showed that the first four hour excretion was almost normal, although the concentration was poor.

April 1: Blood Chemistry: Urea nitrogen, 14; nonprotein nitrogen, 46.7; uric acid, 2.6; creatinin, 1.7; cholesterin, 0.616 per cent.; carbon dioxid, 40.4 . Total serum protein, 5.6 per cent.

April 8: Under the carbohydrate diet which he has been receiving the blood in his urine had entirely disappeared and edema had also disappeared.

April 11: The edema and ascites again increasing; put on a high protein diet consisting of egg, chicken, green peas, 600 c.c. of milk, small amount of cereal and toast.

April 13: Edema steadily increasing. Weight, April 4, 37 pounds; April 12,47 pounds.

April 19: First signs of a diarrhea with mucus, blood and pus in the stools. From April 19 to 24 has had attacks of severe abdominal cramps, frequent 
movements and his ascites and general edema are entirely disappearing. Put on 600 c.c. of protein milk alone. Weight dropped to 40 pounds.

April 26: Still many bowel movements.

Blood Chemistry: Urea nitrogen, 32.2; nonprotein nitrogen, 63 ; uric acid. 4.4 ; creatinin, 2.1 ; cholesterin, 0.496 per cent. Total serum protein, 5.3 per cent. The stool picture shows gram positive bacteria.

April 30: Weight, 33 pounds, 6 ounces. Intake, 1,000 c.c.; excretion, 1,000 c.c. Diet: skimmed milk, hard boiled eggs, toast and split pea soup.

May 6: Still some diarrhea but very much better. Weight, 33 pounds. Excretion very good.

May 11: Phenolsulphonephthalein test. 35 per cent.

Blood Chemistry: Urea nitrogen, 12.6 ; nonprotein nitrogen, 40 per cent.: uric acid, 4.5 ; creatinin, 1.5 ; cholesterin, 0.418 .

Child is out of bed and edema has disappeared.

May 12: Child has had temperature of $103 \mathrm{~F}$., and a rapid recurrence of the edema. The urine contains a good deal of albumin and hyalin casts but no blood.

May 21: Blood pressure, 90/40. The ascites and edema are increasing. Stools are good.

May 24: General condition is very poor. Child is drowsy. Uremia (?); ascites and edema increasing.

May 30: Again frequent bowel movements but no blood in the stool.

June 4: Diarrhea is better. Fundi, negative. Hemogiobin, 72 per cent.

June 14: Home. General condition very good. No edema. Albumin and casts in the urine.

November 19: Seen for reexamination. Has had occasional edema of the face. On a high protein and low fat diet all this time.

Physical Examination. - Child has slight edema of the face and pretibial edema; otherwise negative.

Blood pressure, 100/70. Hemoglobin, 60 per cent.

Blood Chemistry: Nonprotein nitrogen, 56; cholesterin, 0.928 per cent.; serum protein, 4.3 ; cells, 29 per cent.; serum plasma, 71 per cent.

Urine: Albumin, three plus; no casts.

From this it will be seen that although the child was practically free from edema the cholesterin content is the highest yet obtained in this case.

CASE 11 (Hospital No. 208275).-Male, aged 31/2, admitted Feb. 28, 1921. Observed for nine months with a history of edema of six months' duration before admission. The blood nitrogen has never been increased; the blood cholesterin has always been higher than normal, but lowest on last examination. The total serum protein while in the hospital was 6.2 per cent., but has now dropped to 4.2 per cent. The serum has always been milky. The recurrent edema, the absence of increased blood pressure, the urine and blood findings lead us to classify this as a true nephrosis. This case is especially important since the child had diphtheria just before the onset of symptoms.

Family History.-Negative.

Previous History.-Frequent sore throat and enlarged glands. Diphtheria, ten months before admission; tonsils removed two months after diphtheria. Pneumonia, when 2 years old; measles when 1 year old.

Present History.-Six months ago, that is, four months after diphtheria, child's face became swollen, followed by swelling of abdomen and legs. Since then there has been an increasing pallor and weakness, with hematuria on two or three occasions. No headache, vomiting or convulsions. Meat free and salt poor diet for past six months. About ten weeks ago at another hospital in this city where he remained for four weeks. Taken home with generalized edema and passing about 4 ounces of urine a day.

Physical Examination.-Child chronically ill. General edema. Tonsils have been removed. Heart and lungs: negative. Abdomen: distinct fluid wave. Liver: $3 \mathrm{~cm}$. below costal margin. Extremities: moderate edema. 
Laboratory Examination.-Pirquet and Wassermann tests, negative. Hemoglobin, 80 per cent.; erythrocytes, 4,100,000; leukocytes, 12,000; polymorphonuclears, 55 per cent. Blood pressure, 100/80.

Urine: Albumin, three plus; many hyalin and granular casts.

Blood Chemistry: Urea nitrogen, 19.6; nonprotein nitrogen, 53.4 ; uric acid, 2.6 ; creatinin, 1.7 ; cholesterin, 0.592 per cent. Serum, milky.

Diet: Fluids limited to 500 c.c.; milk, cracker and zwieback were given.

March 4 to 10: Salt metabolism estimated. Conclusions of this test are marked water retention, moderate sodium chlorid retention, no nitrogen retention. Intake, 500 c.c. per day; average excretion, 250 c.c.

March 28: Child gradually improving. Put on a diet consisting of cereals, milk, toast and ice cream. Water intake and excretion about the same. Weight, 32 pounds.

TABle 24.-Urine Excretion in Case 11 with and without Water Test March 27: Water Test: Intake, 800 C.c.

\begin{tabular}{|c|c|c|}
\hline Time & $\begin{array}{l}\text { Volume, } \\
\text { C.e. }\end{array}$ & $\begin{array}{l}\text { Specific } \\
\text { Gravity }\end{array}$ \\
\hline $8: 30$ a. m. $\ldots \ldots \ldots \ldots \ldots \ldots \ldots \ldots \ldots \ldots$ & 110 & 1.012 \\
\hline $9: 00$ a.m. & 125 & 1.003 \\
\hline 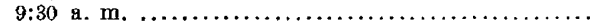 & 214 & 1.003 \\
\hline 10:00 a. m. & 230 & 1.002 \\
\hline 10:30 a. m. & 141 & 1.001 \\
\hline 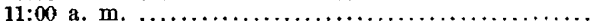 & 48 & 1.008 \\
\hline 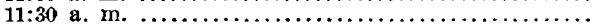 & 14 & 1.012 \\
\hline 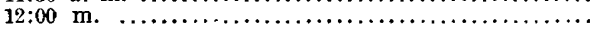 & 18 & 1.014 \\
\hline
\end{tabular}

Total excretion: 900 C.c.

TABle 25.-Urine Excretion and Weight in Case 11

\begin{tabular}{|c|c|c|c|}
\hline Date & Intake & Excretion & Weight \\
\hline 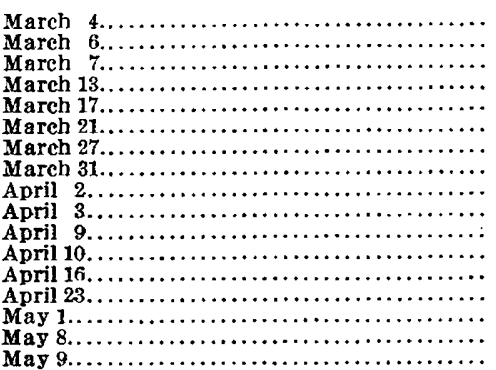 & $\begin{array}{l}600 \\
500 \\
500 \\
500 \\
500 \\
560 \\
800 \\
660 \\
855 \\
720 \\
510 \\
540 \\
500 \\
500 \\
500 \\
500 \\
500\end{array}$ & $\begin{array}{l}400 \\
150+ \\
470 \\
350 \\
400 \\
550 \\
750 \\
700 \\
540 \\
750 \\
800 \\
800 \\
250 \\
225 \\
500 \\
325 \\
350\end{array}$ & $\begin{array}{l}31^{8} \\
30^{5} \\
30 \\
32^{3} \\
32^{4} \\
32^{3} \\
32^{12} \\
31^{13} \\
32 \\
33 \\
33^{4} \\
32^{13} \\
31 \\
31^{12} \\
31^{11} \\
32 \\
32\end{array}$ \\
\hline
\end{tabular}

Blood Chemistry: Serum, milky; urea nitrogen, 16.8; nonprotein nitrogen, 32.2; uric acid, 2 ; creatinin, 1.3 ; cholesterin, 0.696 ; carbon dioxid, 43.3.

April 26: Child still improving; up in chair. Weight, 31 pounds and 12 ounces.

Blood Chemistry: Urea nitrogen, 16.8 ; nonprotein nitrogen, 46.9 ; uric acid, 2.4 ; creatinin, 1.2 ; cholesterin, 0.424 per cent.; total serum protein, 6.2 per cent.; serum sodium chlorid, $5.9 \mathrm{mg}$.

Urine: Albumin, two plus; occasional granular casts.

Blood pressure, 105/85.

May 10: Discharged with the following note: Free from edema. Water excretion about the same as intake. Urine: albumin, two plus, with only a rare cast.

Diet: 500 c.c. of fluid-water and milk-rice or other cereal, potato, vegetables, ice cream. Weight, 32 pounds. 
Return Examination.-November 15: Since discharge from hospital six months ago has had frequent puffiness of the face, but no edema of legs or ascites. Has been on above diet since discharge. Has passed about 12 ounces of urine a day.

Physical Examination.--The child is in fairly good condition; pale; some edema about the eyes. Lungs: little dulness at left base. Heart: not enlarged. Abdomen: no ascites. Lower extremities, no edema. Blood pressure, 89.60.

Laboratory Examination.-Urine: Specific gravity, 1.030; albumin, heavy trace; rare casts. Blood Chemistry: Serum, milky; urea nitrogen, 14; uric acid, 2 ; creatinin, 1 ; cholesterin, 0.376 per cent.; total serum protein, 4.2 per cent.

CASE 13 (Hospital No. 214516).-Male, aged 41/2 years, admitted Oct. 27, 1921. Observed one month in hospital with a previous history of five weeks. Only possible etiology was tooth extraction. The intractable edema despite marked limitation of fluid, the normal blood nitrogen, the high cholesterin, the lowered basal metabolism and the urine findings lead us to classify this case as a true nephrosis. A high protein diet tried for two weeks had no effect.

Family History.-Negative

Previous History.-Child frequently had fairly sore throat. Tonsils and adenoids removed two years ago. Measles, two years ago; pneumonia and otitis media, five months ago.

TABle 26.-Urine Excretion in Case 13 Before and After Water Test Nov. 4, 1921. Water Test: Intake, 350 C.e.

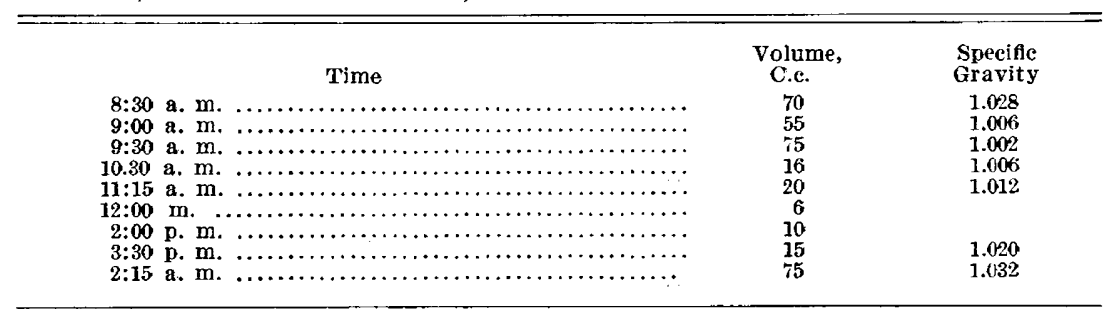

Total four hours, 242 c.c. Total twenty-four hours, 342 e.c.

Present History.-About five weeks ago had a tooth extracted. Almost immediately after that it was noticed that child had puffiness of eyelids, but in the course of two weeks it had disappeared. About ten days ago the edema reappeared and rapidly involved the body and the extremities.

Physical Examination. - Child chronically ill. General anasarca. Face: edematous. Eyes: almost closed; swelling of the lids. Throat: slightly congested. Lungs: little flatness and diminished breathing at right base. Heart: negative. Abdomen: distended with fluid wave. Marked edema of scrotum and penis. Extremities: marked edema.

Laboratory Examination.-Pirquet and Wassermann test, negative. Hemoglobin, 90 per cent.; erythrocytes, $5,470,000$; leukocytes, 17,000; polymorphonuclears, 73 per cent. Blood pressure, 98/68.

Urine: albumin, four plus; many casts and a few white blood corpuscles.

Blood Chemistry: Serum, clear; urea nitrogen, 12.6; nonprotein nitrogen, 32.9; creatinin, 1.2 ; cholesterin, 0.552 per cent.

Phenolsulphonephthalein Test (intramuscular): Excretion first hour, 12 per cent.; second hour, 8 per cent.; total, 20 per cent.

Diet: Milk, 500 c.c. for four or five days; later reduced to 350 c.c. Weight, 37 pounds and 6 ounces.

November 8: Given thyroid, $1 / 2$ grain, twice a day. Discontinued after two days.

November 11: Phenolsulphonephthalein Test (intravenous): Total excretion, 50 per cent. after two hours. 
November 13: Child had not improved. Weight, 5 pounds more than on admission. Put on high protein diet, consisting of 350 c.c. skimmed milk; two eggs ; chicken, $50 \mathrm{gm}$.; peas, $20 \mathrm{gm}$.; farina once a day.

November 14: Southey tubes applied to lower extremities; about 60 c.c. of edema fluid obtained. Analysis of edema fluid: specific gravity, 1.005; cholesterin, 0.012 per cent.; sodium chlorid, 0.643 per cent. Basal metabolism, 20 per cent. Blood pressure, 80/60.

CASE 16 (Hospital No. 210059).-Male, aged 2, admitted May 9, 1921. Child has had edema for eight months. Etiology, probably scarlet fever. Has had all modes of treatment, protein free diet, high protein diet, diuresis, thyroid, decapsulation of kidney, without any effect. The urine always contained large amounts of albumin and casts; the blood urea became high during the latter part of the illness. The cholesterin always remained high, but what was most surprising, the serum protein was not decreased. Child finally died. A typical case of nephrosis.

Table 27.-Urine Excretion and Weight in Case 13

\begin{tabular}{|c|c|c|c|}
\hline Date & Intake & Exeretion & Weight \\
\hline Oetober $28, \ldots \ldots \ldots \ldots \ldots \ldots \ldots \ldots \ldots \ldots$ & .. & 315 & $37^{6}$ \\
\hline 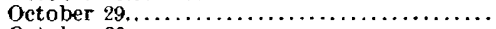 & $\ldots$ & 300 & \\
\hline October $30, \ldots \ldots \ldots \ldots \ldots \ldots \ldots \ldots \ldots \ldots \ldots$ & ... & 60 & \\
\hline October $31 . \ldots \ldots \ldots \ldots \ldots \ldots \ldots \ldots \ldots \ldots \ldots \ldots \ldots \ldots \ldots$ & $\cdots$ & 250 & \\
\hline November $1 \ldots \ldots \ldots \ldots \ldots \ldots \ldots \ldots \ldots$ & 690 & $1 \geq 0$ & \\
\hline November $2 \ldots \ldots \ldots \ldots \ldots \ldots \ldots \ldots \ldots \ldots \ldots \ldots$ & 830 & $\because 00$ & \\
\hline November $3 \ldots \ldots \ldots \ldots \ldots \ldots \ldots \ldots \ldots$ & 600 & 300 & $4:$ \\
\hline 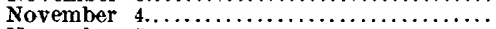 & 300 & 300 & \\
\hline November $5 \ldots \ldots \ldots \ldots \ldots \ldots \ldots \ldots \ldots \ldots$ & 550 & 240 & \\
\hline November $6 \ldots . . . \ldots \ldots \ldots \ldots \ldots \ldots \ldots \ldots \ldots \ldots$ & 600 & 180 & \\
\hline November $7 \ldots \ldots \ldots \ldots \ldots \ldots \ldots \ldots \ldots$ & 300 & 360 & \\
\hline 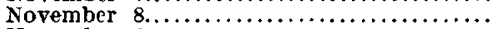 & 30 & 18 & \\
\hline 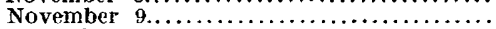 & आ) & 36 & \\
\hline November $10, \ldots \ldots \ldots \ldots \ldots \ldots \ldots \ldots \ldots \ldots$ & 390 & 150 & $42^{2}$ \\
\hline November $11 \ldots \ldots \ldots \ldots \ldots \ldots \ldots \ldots$ & 360 & 210 & 495 \\
\hline November $12 . . \ldots \ldots \ldots \ldots \ldots \ldots \ldots \ldots \ldots \ldots \ldots \ldots \ldots \ldots$ & 360 & 90 & \\
\hline November $13 . \ldots \ldots \ldots \ldots \ldots \ldots \ldots \ldots \ldots \ldots \ldots$ & 300 & 420 & $42^{3}$ \\
\hline November $14 \ldots \ldots \ldots \ldots \ldots \ldots \ldots \ldots \ldots \ldots$ & 360 & 240 & $42^{12}$ \\
\hline November $15, \ldots \ldots \ldots \ldots \ldots \ldots \ldots \ldots \ldots \ldots$ & 390 & 210 & 4914 \\
\hline November $16 \ldots \ldots \ldots \ldots \ldots \ldots \ldots \ldots \ldots$ & 423 & 150 & $43^{s}$ \\
\hline 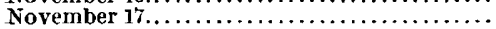 & 330 & $?$ & $43^{5}$ \\
\hline November $18 \ldots \ldots \ldots \ldots \ldots \ldots \ldots \ldots \ldots$ & 360 & ? & 44 \\
\hline 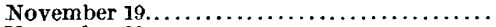 & 480 & $4: 0$ & $45^{2}$ \\
\hline 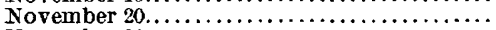 & $4=0$ & 120 & $47^{3}$ \\
\hline November $21 \ldots \ldots \ldots \ldots \ldots \ldots \ldots \ldots \ldots \ldots \ldots$ & 270 & 270 & $45^{4}$ \\
\hline November $22, \ldots \ldots \ldots \ldots \ldots \ldots \ldots \ldots \ldots \ldots$ & 480 & 210 & 4510 \\
\hline 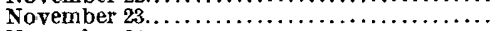 & 350 & 200 & $43^{11}$ \\
\hline November $24 \ldots \ldots \ldots \ldots \ldots \ldots \ldots \ldots \ldots \ldots \ldots$ & $3 \times$ & $85+$ & 46 \\
\hline November $25 \ldots \ldots \ldots \ldots \ldots \ldots \ldots \ldots \ldots \ldots$ & $3: 0$ & $239+$ & $46^{2}$ \\
\hline November $26 \ldots \ldots \ldots \ldots \ldots \ldots \ldots \ldots \ldots \ldots \ldots \ldots \ldots \ldots$ & 350 & $150+$ & 47 \\
\hline November $27 \ldots \ldots \ldots \ldots \ldots \ldots \ldots \ldots \ldots \ldots$ & ... & $\cdots$ & $47^{2}$ \\
\hline
\end{tabular}

Family History.-Three children. Mother had three miscarriages after birth of second child; otherwise negative.

Previous History.-Whooping cough when 7 months old; when 1 year old, fairly severe burn on body which healed in three weeks.

Present History.-About six weeks before admission an older sister of patient had scarlet fever. About this time this child had a mild rash for one day with temperature. One month before admission child fell a great deal, and it was then noticed that his legs were swollen and that he passed very little urine. Urine examined and albumin found but no blood.

Physical Examination.-Patient acutely ill. Generalized edema. Eyes almost closed because of swelling of lids. Ears: purulent discharge from right ear. Throat: tonsils ragged; not congested. Lungs: dulness at both bases. Heart: not enlarged. Abdomen: very much distended with shifting dulness. Extremities: swollen. Weight, 29 pounds.

Laboratory Examination.-Hemoglobin, 74 per cent.; erythrocytes. 5,500,000; leukocytes, 15,400; polymorphonuclears, 60 per cent. 
May 9: Urine: specific gravity, 1.030; albumin, four plus; many hyalin and granular casts and rare leukocytes.

Blood Chemistry: Urea nitrogen, 18.2; uric acid, 1.5; cholesterin, 0.376 per cent.; carbon dioxid, 34.7; sodium chlorid, 5.5; serum protein, 5.77 per cent.

Pirquet and Wassermann tests, negative. Blood pressure, 90/60.

Diet: Water, 500 c.c.; sugar. $90 \mathrm{gm}$.

May 13: Put on high protein diet. Southey tubes were inserted in lower extremities. For next few weeks no improvement in the edema. Blood Examination: Urea nitrogen, 32.2 ; nonprotein nitrogen, 66.5 ; uric acid, 2 ; creatinin, 1.6; cholesterin, 0.532 per cent. Plasma Volume: cells, 24 per cent.; plasma, 76 per cent. Weight, 32 pounds.

June 9: Transferred to surgical service where double decapsulation of kidneys was done. Kidneys, large and pale.

June 25: Transferred to medical service. During stay in surgical ward there was not much change in the edema. Fundi were normal. Blood Chemistry: Urea nitrogen, 23.8 ; cholesterin, 0.308 per cent. Diet: fruit juices, vegetable. milk, 800 c.c. Within next few days child became very edematous. Diet consisted of 350 c.c. of milk.

July 11: Thyroid, $1 / 4$ grain, three times daily, given. One week later gelatin and cream cheese added to diet. This was followed by diarrhea, but edema became less marked. Urine could not be measured, but child was voiding a fair quantity. Two weeks later edema again increased. Put back on high protein diet and 10 grains urea chlorid, given three times a day. Weight, 25 pounds.

August 24: Blood Chemistry: Urea nitrogen, 47.6; cholesterin, 0.360; protein, 7.15 per cent.

September 3: No improvement. Given diuretic.

September 14: Paracentesis, 300 c.c. fluid obtained. Previous diet discontinued; put on 400 c.c. milk.

September 19: Put back on high protein diet.

September 30: Taken home against advice with no improvement. Urine remained the same throughout the entire stay in hospital, containing albumin, four plus, and casts but no blood cells. Discharge weight, 23 pounds, 5 pounds less than upon admission.

A few days later child was taken to Babies' Hospital, New York. No improvement. Child was transfused but died within two weeks. 